Literature

ӘАәбият

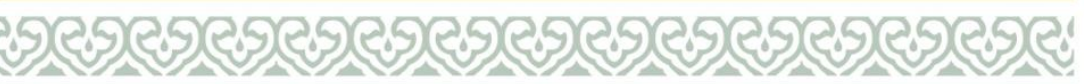

Аитература

DOI: $10.26907 / 2311-2042-2020-15-2-34-53$

\title{
THE ASSIMILATION OF MAGZHAN ZHUMABAYEV'S WORKS INTO THE TATAR CULTURE
}

\author{
Ainur Kasimzhanovna Mashakova, \\ M. Auezov Institute of Literature and Art, \\ 29 Kurmangazy Str., Almaty, 050010, Kazakhstan, \\ a_mashakova@mail.ru.
}

\author{
Mileusha Mukhametzyanovna Khabutdinova, \\ Kazan Federal University, \\ 18 Kremlyovskaya Str., Kazan, 420008, Russian Federation, \\ mileuscha@mail.ru.
}

\begin{abstract}
The article is devoted to the problem of literary and cultural relationships between the Tatars and the Kazakhs. The study is focused on the assimilation of the Kazakh poet Magzhan Zhumabaev's creative work into the Tatar culture. The sources used are translations of the poet's works into Tatar, N. Isanbet's article "The History of One Epigraph" and R. Tukhvatullova's novel "The Wind of Fate". Studying archival materials enabled the researchers to reveal the contribution of Tatar scholars and writers to the revival of the legacy of the famous Kazakh poet, who became a victim of Stalin's repressions.
\end{abstract}

Key words: Kazakh and Tatar literary and cultural relationships, Tatar literature, textual criticism, M. Zhumabaev, G. Ibragimov, N. Isanbet, S. Kudash, Abai Kunanbaev, V. Bryusov, N. Arslan, M. Aglyam, R. Gatash, F. Tarkhanova, R. Tufitullova.

The spiritual ties between Tatar enlighteners and related Turkic peoples, which developed at the end of the $19^{\text {th }}$ century, became especially active at the beginning of the $20^{\text {th }}$ century when these peoples got independence. Bashkir, Uzbek, Turkmen, Kazakh, Kyrgyz, Kumyk, Azerbaijani, KaraKalpak, and Uighur shakirds studied in Tatar madrasahs such as "Muhammadiya", "Galiya",
"Khusainiya", "Mutigiya" in Kazan, Ufa and other cities of Russia. Besides, the famous Tatar intellectuals G. Ibragimov, N. Dumavi, Sh. Babich, Kh. Taktash and others went to the regions where the Turkic peoples lived, disseminated knowledge and enlightenment among the local population, taught in schools, and contributed their works to the periodical press. This connection further promoted the 
development of culture and literature of the Turkic-speaking peoples. The tradition became planned and systematic in the 1920s and 1930s, acquiring an ideological and political character. Burnasheva (Giffat-tutash) and other scientists, writers and public figures played a crucial role in the development of general secondary and higher education, the humanities, and the national culture of fraternal peoples. The history of spiritual and cultural relations between the Tatar and Turkicfraternal peoples is of great interest to scientists and creative figures (R. Ganieva [Ganiyeva, 2002], A. Akhunov [Akhunov, 2010,], D. Galiullina [Galiullina, 2010], Ch. H. Gilazeva [Gilazeva, 2012], T. Gilazov [Gilazov, 2019], etc. The cultural and literary relationships between the Kazakhs and the Tatars have repeatedly become the subject of research by Tatar and Kazakh scholars (B. Iskhakov [Iskhakov], [Yskakov], M.Kh. Gainullin [Gainullin], R.K. Ganieva [Ganieva, 1988], [Ganieva, 2014], A. Karimullin [Karimullin], Kh. Yu. Minnegulov [Minnegulov, 2015], [Minnegulov, 2020], T. Karimov [Karimov, 2008], [Karimov, History...], [Karimov, On "The Word about Magzhan"...].

A number of articles have been published for the past five years as a result of the cooperation of the researchers from the M. Auezov Institute of Literature and Art (the Republic of Kazakhstan) and Kazan Federal University (the Russian Federation): by A. Nasyrova, M. Khabutdinova, A. Khabutdinov [Nasyrova, Khabutdinov, Khabutdinova], by L. Fattakhova, A. Mashakova, M. Khabutdinova, L. Zamalieva [Fattahova, Khabutdinova, Mashakova, Zamalieva], by A. Mashakova, M. Khabutdinova [Mashakova, Khabutdinova, 2017], [Mashakova, Khabutdinova, 2018], [Mashakova, Khabutdinova, 2019], by M. Khabutdinova, A. Mashakova [Mashakova, Khabutdinova], by M. Khabutdinova [Khabutdinova]).

The Kazakh researchers (R. Nurgali [Nurgali], Sh. Eleukenov [Eleukenov], B. Zhetpisbaeva [Zhetpisbaeva], K. Mukanov [Mukanov], B. Zhanguttin [Zhangutin] made a huge contribution to the studies of the great Kazakh poet's works.

However, we regret to state that the information about the contribution of Tatar scholars and writers to the study of Magzhan Zhumabaev's work has not been systematized yet.

Magzhan Zhumabaev was born in the Sasykkul tract, the Poludinskaya volost of the Petropavlovsk district in 1893. Due to the fact that his father was a volost governor, Magzhan had the opportunity to receive what at that time was considered a very good education. At the beginning, he was educated at home, then continued his studies at the local madrasah. In the autumn of 1910, he entered the famous Ufa madrasah "Galiya" (1909-1910). He communicated with famous Tatar and Bashkir writers, such as Galimzhan Ibragimov, Shaekhzade Babich, Mazhit Gafuri, Saifi Kudash. Following G. Ibragimov's advice, Magzhan entered the Omsk Teachers' Seminary in 1913. In 1918, he was arrested and spent 7 months in prison.

His first poetry collection "Chulpan" was published in the Karimovs' printing house in Kazan in 1913. As N. Arslan notes, "This lyrical collection spread the fame of Magzhan's great talent" [Arslan]. In 1922-1923, some collections of his poems were published in Kazan and Tashkent.

Magzhan Zhumabaev was not only a poet, but also a teacher. In 1918, he was the head of teacher training courses in Omsk and Petropavlovsk. In 1922, his book "Pedagogy" was published in Orenburg.

In 1922, M. Zhumabaev was invited to the Kazakh-Kyrgyz Institute of Education. In December, 1923 he went to Moscow. He was invited by Anatoly Lunacharsky to teach oriental languages at Communist University for Workers of the East where he wrote textbooks for Kazakh schools. In 1923, upon the recommendation of N. Tyurakulov and Prof. Polivanov he was enrolled at the Moscow Literature and Art Institute named after V. Bryusov [Zhangutin, p. 228]. In Moscow, M. Zhumbaev closely communicated with V. Bryusov, S. Yesenin, Vs. Rozhdestvensky, O. Mandelstam, and M. Svetlov (See also [Zhetpisbaeva, 2008], [Zhetpisbaeva, 2012] for more details). Thanks to his excellent command of the Russian language, he used the collections of works by A. Pushkin, A. Blok, M. Tsvetaeva, and A. Akhmatova as his reference books. He translated poems by Goethe, Heine, Byron, Lermontov, Fet, Koltsov, Vs. Ivanov, and prose by M. Gorky and Mamin-Sibiryak into the Kazakh language. But when because of V. Bryusov's death, the Institute was closed, M. Zhumabaev was unable to complete his studies. In 1927-1929, the poet returned to Petropavlovsk and began to teach at the Kazakh Pedagogical College.

M. Zhumabaev's admirers saw him as the successor of Abaev's traditions, while the members of the Proletkult (Proletarian Culture - an experimental Soviet artistic institution that arose in conjunction with the Russian Revolution of 1917) saw him as a bourgeois, nationalist, reactionary poet and an Alash 
devotee $^{1}$ (the Kazakh Democratic Party and Liberation Movement). In 1924, his work was deemed ideologically unstable at the meeting of the staff of Communist University for Workers of the East in Moscow. In December of the same year, a "literary trial" was held dedicated to M. Zhumabaev's work, which ended with a verdict proclaiming him an antiSoviet writer. Due to the fact that he took part in developing the creative curriculum of the Kazakh writers' collegium "Alka", he was arrested on the charge of nationalism in 1929. After having been interrogated in Butyrka prison, he ended up in one of the Karelian detention camps. In 1935, the poet wrote a letter to Maxim Gorky and was released on parole upon the request of the famous writer and his wife E. Peshkova... In 1936-1937, he returned to Petropavlovsk again and started teaching the Russian language and literature at the school named after A. Pushkin. At the invitation of the poet and prose writer Saken Seifullin, he moved to Almaty, but got arrested again and executed by shooting in March 1938 [Tarkhanova, pp. 93-94]. On 8 July, 1960, he was rehabilitated by the decision of the Military Court of the Turkestan Military District, but his works became available for readers only in 1989 [Zhomabaev, 1989], [Magzhan Zhomabaev]).

In 1960, Tatar, Bashkir, and Kazakh writers made a lot of efforts to return M. Zhumabaev's works to people. In 1965, Khairulla Makhmudov, Doctor of Philology, Head of the Department of Philology of Kazakh State University, and Ivan Shukhov, a writer and the editor-in-chief of the "Prostor" magazine, decided to present Magzhan Zhumabayev's creative work to readers. The translation of the poems was prepared for the magazine by the famous linguist Alexander Zhovtis. However, this initiative collapsed due to censorship.

In 1967, Kh. Makhmudov tried again. He made a presentation on the importance and necessity of returning the legacy of $\mathrm{M}$. Zhumabaev to the readers at a joint meeting of seven departments of the Faculty of Philology and two departments of the Faculty of Journalism of Kazakh State University. Prof. Kh. Makhmudov was supported by the writer Takhavi Akhtanov, Prof. Temirgali Nurtazin, the literary critic Nikolai Rovensky, Prof. Beisenbai Kenzhebaev and the writer and translator Alexander Zhovtis. As a result of the meeting, the schol-

\footnotetext{
${ }^{1}$ The Alash movement was a national liberation movement against the colonial policy of the Russian Empire that was formed in the first quarter of the $20^{\text {th }}$ century on the territory of the Kazakhs. In 1917-1920, the Alash party emerged on the basis of this movement.
}

ars sought assistance of the Association of Writers in publishing the poet's works and his translations of Lenin, Gorky, Goethe, Heine, Lermontov, and Byron into Kazakh.

The copies of Makhmudov's report and the decision of the meeting were sent to the Minister of Culture of the Kazakh SSR Ilyas Omarov, to the Council of Nationalities of the Supreme Soviet of the USSR, to the Board of the Association of Writers of the Russian Soviet Federative Socialist Republic, to the writer Leonid Sobolev and to the "Literaturnaya Gazeta". However, the Department of Science and Educational Institutions of the Central Committee of the Communist Party of Kazakhstan reacted negatively to this initiative. They began an investigation and received the certificates on archival and criminal cases from the KGB of the Kazakh SSR. At the special meeting of the Bureau of the Central Committee in 1967, it was noted that the poet had not yet been rehabilitated, but despite this during at the meeting of philological departments "the speakers tried to exalt him in every possible way, considering him to be a classic of Kazakh poetry repressed during the period of the personality cult". The decree of the Bureau of the Central Committee "On the wrong decision of the philological departments of KazSU in assessing the poetic heritage of Zhumabaev" stated that it was necessary "to condemn the wrong decision of the philological departments of the Kazakh State University in the assessment of the poetic heritage of the bourgeois and nationalist poet Magzhan Zhumabaev" [Karimov, 2015].

Naki Isanbet spent one month in Almaty in the summer of 1965, he went to a sanatorium there and closely communicated with the scholars of $\mathrm{Ka}$ zakhstan. N. Isanbet made a contribution to $\mathrm{M}$. Zhumabaev's rehabilitation. His archives contain the article "The History of One Epigraph" [Isanbet]. This material was aimed to commemorate G. Ibragimov's $80^{\text {th }}$ birthday, but due to the censorship it was not included in the anniversary issue of the magazine "Kazan utlary" dedicated to G. Ibragimov, so the article remained unpublished.

Outlining the life of the Kazakh poet, the Tatar writer points out that Zhumabaev taught history of Kazakh literature and stylistics of the Kazakh language at Moscow Communist University for Workers of the East. Emphasising the poet's success in the field of translation, N. Isabnet comes to the conclusion that "in the Soviet East, M. Zhumabaev was one of the most educated, versatile, competent, progressive literary critics, a major stylist and cultural figure" [Isanbet, p. 5]. 
Reflecting on the poet's poems, published in the Tatar newspapers and the collection "Chulpan", N. Isanbet shared the following observation: "Although Magzhan received a patriarchal education, he was not the one whose "neck was captured by a lasso", and whose mouth was controlled by bridles". He felt a responsibility only to his own conscience, therefore, as a poet, he did not obey any doctrine, he said what he meant and what he believed in. It is known that this tradition was introduced by the older generation of poets such as Byron, Schiller, Lermontov, and Tukai, who did not fit into the social framework of their epoch; in general, it was not easy for them" [Isanbet, p. 6].

To mislead the censorship, N. Isanbet dwells on M. Zhumabaev's teachers in his article: "Magzhan began to write poetry under the influence of the great Abai, the founder of Kazakh poetry. He recognized him as his mentor (for example, in the poem "To the Glorified Akyn, the Golden-Voiced Khakim Abai" written in 1911 in Ufa). Just like Abai, M. Zhumabaev used the hendecasyllable of Kazakh national verse in most of his poems. The Tatar scholar considered it important to note that $\mathrm{M}$. Zhumabaev, avoiding slavish imitation, managed to make his own statement in Kazakh poetry: "However, Magzhan did not turn into Abai's simple epigone, but managed to kick off from this tradition and give a new impetus for the progressive development of Kazakh poetry. He began to formulate verses, rhythm and metrics in a new way in order to convey a psychologically reliable idea. He revived the poem with playful intonations, gave them a new sound. The verses that he used were not confined to hendecasyllable (consisting of 11 syllables), but could also consist of 4, 5, 6, 7 or more syllables. He was able to create the poetic context in which emotions and content were an inseparable whole, and the poem was not fragmented for the sake of conveying feelings and meaning in separate lines.

In his article, $\mathrm{N}$. Isanbet cited an extract from M. Zhumabaev's poem created in Ufa in 1911 and dedicated to Abai:

\begin{tabular}{|l|l|}
\hline Йөргән жанның-артында & A traveling soul will have \\
эзе калыр, & a trace, \\
Итекче үлсә, чүкеч белән & If a felt boots feller dies, he \\
безе калыр, & will leave a hammer and an \\
Бер бай үлсә, дүрт & awl, \\
төрледән малы калыр, & If a bai dies, he will leave \\
Чичән үлсә, артында сүзе & four types of cattle ${ }^{2}$, \\
\hline
\end{tabular}

\footnotetext{
${ }^{2}$ The four types of cattle include the horse, the camel, the cow and the sheep (The note by N. Isanbet)
}

\begin{tabular}{|l|l|}
\hline калыр. & $\begin{array}{l}\text { If a singer }{ }^{3} \text { dies, he will } \\
\text { leave his word. } \\
\text { Шомлы дөнья } \\
\text { куштанлеd times will come } \\
\text { to an end, adjusting, } \\
\text { Most of the survivors will } \\
\text { үтәр, }\end{array}$ \\
Сау калганның күбесе & The dawn, \\
иртән бетәр, & not stop running, \\
Туктамас бу дөньяның & The singer's word will \\
тәгәрмәче, & reach the ears of many. \\
Чичәннең әйткән сүзе & (here and further lit. trans- \\
күпкә житәр. & lation by O. Bezuglova) \\
(translated from Kazakh by & \\
N. Isanbet) &
\end{tabular}

In his article, $\mathrm{N}$. Isanbet claims that the artistic world of the Kazakh poet was also beneficially influenced by Russian poetry: "V. Bryusov called Magzhan Kyrgyz / Kazakh Pushkin. Indeed, there is not a single non-poetic line in this poet's works. It is obvious that he studied the traditions of Kazakh folk literature and Abai, the heritage of Russian and foreign classics and was interested in the achievements of Russian contemporary poets such as Blok, Bryusov and symbolists" [Isanbet, p. 7].

The author is glad to describe the Kazakh poet's literary contacts with Tatar writers: "However, what is most important to us is that he not only got acquainted with Tatar poetry, but also tried to use the best advanced experience, became interested in the poetry of Tukay and Derdemend.

For example, his long poem-lullaby "Besik Kyry" ("A Lullaby Song") was written under the influence of "Bellu" ("A Lullaby") by Derdemend and repeated its meter "yazylgan". Magzhan resembles Shaekhzade Babich with his ethnic spirit, sparkling wit, humour, and emotionality. Of course, they both studied in the madrasah "Galia", but I do not know whether they knew each other personally, because Babich entered the madrasah later" [Isanbet, p. 7].

$\mathrm{N}$. Isanbet depicts in detail the contacts of $\mathrm{M}$. Zhumabaev with G. Ibragimov. "G. Ibragimov and Magzhan studied at "Galiya" at the same time, so they were personally acquainted with each other. In the book "Kara Mayaklar" ("Black Beacons") published in 1924, G. Ibragimov mentioned Magzhan Zhumabaev's name on page 48 and put him on a par with Abai Kunanbayev as his talented follower"4 [Kara mayaklar yaki ak edebiyatlar, p. 48].

$\mathrm{N}$. Isanbet emphasizes the positive role of $\mathrm{G}$. Ibragimov in resolving the conflict around the

\footnotetext{
3 "Singer" here means a public speaker.

"It's about a book" Black lighthouses or White literature "[Kara mayaklar yaki ak edebiyatlar].
} 
handwritten literary journals of shakirds in the Tatar and Kazakh languages: "Once in Ufa in the "Galiya" madrasah, the head of the literary circle Babich began to publish a handwritten journal "Parlak". Kazakh shakirds decided not to lag behind and began to publish the journal "Sadak" in Kazakh. Several shakirds were against this initiative, so they made a scandal: "Galiya" is a Tatar madrasah, why should they publish it in Kazakh?" This led to aggravation of national relations. He gave a serious speech defending the rights of the Kazakh literary movement and called it stupid to ignore the existence of the original Kazakh literature, represented by many writers such as akin Kunanbaev, Saydullin, Dulatov, and to encourage all Turkic peoples to fit into the framework of one Turkic language, not to notice books and newspapers published in their native languages. The Shakirds who supported G. Ibragimov congratulated the Kazakh shakirds (1913)" [Isanbet, p. 2].

$\mathrm{N}$. Isanbet praises G. Ibragimov's article "Tellere bashka bulsa da kunellere ber" ("Although the Languages are Different, but Feelings are Common"), published in the journal "An" ("Consciousness") in 1916: "This article is worthy of particular attention. G. Ibragimov wrote that modern Turkic literature is like a tree with five branches: Ottoman, Azerbaijani, Tatar, Uzbek, and Kazakh literature. As he believes we might admit their mutual influence on each other, but these are independent literatures. The most important thing for us in this article is that G. Ibragimov not only defends Kazakh literature, but also draws attention to its original beauty, speaks highly of it and encourages to study its best sides. It was a revolutionary statement for its time, a new word" [Ibrakimov, 2019, pp. 114-120].

According to N. Isanbet, G. Ibragimov defends the idea of the originality of Kazakh literature, based on the works of turkologists:

"All turkologists admit that it is the Kazakh territory where the ancient traditions of the Turks have been preserved. So far, the Kazakh people have always stood out among other Turkic peoples ${ }^{5}$ with their original way of life and opportunities. There is some kind of original identity in the spirit of these people. Their folklore is incomparably richer and more unique than that of other peoples. We must begin a large-scale study of Kazakh folk literature in order to enrich the literary treasury, and not drive it into the framework of the "Ta-

\footnotetext{
${ }^{5}$ Haet - humdrum. The note by N. Isanbet.
}

tar language and Tatar literature" [Ibragimov, 2019, pp. 117-118].

$\mathrm{N}$. Isanbet further writes that the scientist and public figure G. Ibragimov, despite the difficult conditions and hard times, in his every action defended the Tatar nation, investing tremendous effort in the development of Tatar culture.

"However, this statement does not mean that Galimzhan Ibragimov ignores other literatures, giving priority to Kakhakh literature. It is known that in 1922, in the years of famine, devastation, and exacerbation of the class struggle, when the Soviet republic was being created, G. Ibragimov was in charge of the research centre and published a lot of large novels. Apart from his literary activity, he was in the centre of the social movement and strove to convey his opinion on every dimension, be it criticism or education" [Isanbet, p. 2].

In his article, $\mathrm{N}$. Isanbet also sheds light on the source of the epigraph to the novel "Kazak kyzy" ("The Daughter of the Steppe") by G. Ibragimov: "There are 9 dots under the epigraph. It looks as if the number of the letters corresponds to the spelling of M. Zhumabaev or M. Zhumabay" [Isanbet, p. 8].

\begin{tabular}{|c|c|c|}
\hline $\begin{array}{l}\text { Көң дала, } \\
\text { көресің zой, ана } \\
\text { жаткан, } \\
\text { Жібектей жасыл } \\
\text { төптер бетін } \\
\text { жапдан, } \\
\text { Аскар тау, } \\
\text { балдан тәтте } \\
\text { сулары бар, } \\
\text { Әнә сол анам } \\
\text { өді мени талкан. }\end{array}$ & $\begin{array}{l}\text { Киң дала, } \\
\text { күрәсең ич, әнә } \\
\text { яткан, } \\
\text { Ефәктәй яшел } \\
\text { чирәм битен } \\
\text { япкан, } \\
\text { Күктәш тауб, } \\
\text { балдан татлы } \\
\text { сулары бар, } \\
\text { Әнә шул анам } \\
\text { иде, мине тап- } \\
\text { кан. } \\
\text { “Тһе Moon” by } \\
\text { M. Zhumabaev. }\end{array}$ & $\begin{array}{l}\text { You can see the } \\
\text { spacious steppe, } \\
\text { how it spreads, } \\
\text { It covered the } \\
\text { face of the earth } \\
\text { with green silk. } \\
\text { At a sky-high } \\
\text { mountain, the } \\
\text { water is sweeter } \\
\text { than honey, } \\
\text { This is what my } \\
\text { mother, who } \\
\text { gave birth to me, } \\
\text { was like. }\end{array}$ \\
\hline
\end{tabular}

$\mathrm{N}$. Isanbet defines the meaning of this epigraph as follows: "this quatrain full of deep meaning is used as a key to the novel "Kazak kyzy" ("The Daughter of the Steppe"). This is the author's leitmotif referring to the theme of the novel. This key helps us to see G. Ibragimov's connection to life and literature, the culture of the Kazakh people, allowing us to understand the content of the novel more profoundly".

\footnotetext{
${ }^{6}$ Күктәш тау - mountain reaching the heaven. In Kazakh it is "Askar tau", as Professor Khairulla Makhmudov explains, in Tatar it is given in this spelling. The note by N. Isanbet.
} 
The Tatar scholar believes that G. Ibragimov had a reverential attitude towards the Kazakh people and their culture: "It is obvious that G. Ibragimov had formed his attitude to the rich $\mathrm{Ka}$ zakh folk literature and language long before these disputes. This is indicated by the much-maligned first version of the novel "Kazak kyzy" ("The Daughter of the Steppe"), written in 1909. Each line of this novel is permeated with great love for the Kazakh people".

$\mathrm{N}$. Isanbet believed that it was no coincidence that the writer's gaze turned to the Kazakhs. G. Ibragimov, as a romanticist, was sure that these Turkic people preserved their identity at the beginning of the $20^{\text {th }}$ century and did not fall victim to bourgeois relations: "It's not unjustified that the revolutionary Galimzhan turned his gaze to the Kazakhs, who did not have time to survive the phase of capitalism, and who are often looked down because of their nomadic way of life. He devoted a novel to them, having plunged deeply into their lives. The reason is that the Kazakhs were not affected by the bourgeois philistinism, they managed to preserve freedom of spirit and naturalness in themselves."

"The Tatar world was meant to wake up from hibernation thanks to the beauty created by the young G. Ibragimov, who was immersed in romantic dreams of freedom, thanks to the image of the Kazakh girl Karlygachsylu, participating in horse racing! The poem "Kazak kyzy", written in 1916 by F. Burnash, was one of the most beautiful manifestations of these romantic whims," N. Isanbet concludes. In the article, N. Isanbet considers the novel, on the one hand, as a creative laboratory of the writer, revealing the specifics of artistic thinking; on the other hand, as his theoretical activity. in the context of the connections between them. The value of the work is the rich folk oral art of the Kazakh nation presented to the Tatar reader, the artistic embodiment of the fraternal people's life and the positive influence of the rich Kazakh language on the Tatar literary language.

Further, the scholar dwells on the meaning and originality of the novel "Kazak kyzy", "In the 1910s, G. Ibragimov knew a wealth of romantic writing techniques, at the same time he showed a real social potential as a scholar and a realist relying on solid scientific methods and logical deduction. This dual nature of his is reflected in his work and explains the originality and persistent interest in the novel "Kazak kyzy" ("The Daughter of the Steppe"). However, it is not only due to his ability to see the originality of the huge and rich treasury preserved by the Kazakh people, which we did not have or have lost. This treasury is folk literature. Most importantly, he was able to successfully demonstrate the consistency of his statement, his novel "Kazak kyzy" ("The Daughter of the Steppe") is relevant both in terms of strengthening friendship between peoples, and in terms of poetic skill in depicting the life of one of our kindred peoples. His novel became a significant phenomenon in our literature. In this work, he was able to demonstrate the richness of the folk language and to introduce folk art techniques as stylistic devices that contribute to the further prosperity of the Tatar literary language. And this is what makes this works of art so special" [Isanbet, p. 4].

G. Ibragimov highly appreciated the skill of $\mathrm{M}$. Zhomabaev in depicting lyrical landscape, based on the internal nature of this genre, revealing the picturesque beauty of the natural phenomenon, the spiritual world of the poet, and creating the lyrical hero-Kazakh: "It would not be an exaggeration to say that in Kazakh poetry no one created this kind of lyrical poetry in large quantities, he was a pioneer. Nature in his poems expresses the poet's mood, it is animated, it turns into a new image that carries a new meaning, which is full of lyrical warmth, sounding innovative thanks to the language of feelings. Magzhan's palette is unusually rich in colours and shades. This can be clearly seen in the quatrain which G. Ibragimov uses as an epigraph: the landscape worthy of the Alatau Kazakhs together with the boundless steppe demonstrate all the boundlessness of the Kazakh spirit, its greatness and spaciousness, this is boundless mother nature that gave birth to the Kazakhs, their life is closely intertwined with each other, promoting mutual birth, which makes a Kazakh person.

Perhaps G. Ibragimov drew attention to this stanza for this reason" [Isanbet, pp. 8-9].

$\mathrm{N}$. Isanbet believes that the Kazakh poet successfully exploited symbolist techniques like Blok and Derdemend. According to the Tatar writer, this is clearly manifested in the poem "Dulkyn":

\begin{tabular}{|l|l|}
\hline \multicolumn{1}{|c|}{ “Дулкын” } & \multicolumn{1}{|c|}{ A wave } \\
Дулкыннан дулкын туа- & $\begin{array}{l}\text { A wave is born from an- } \\
\text { other wave }\end{array}$ \\
дыр, & A wave drives another \\
Дулкынны дулкын куа- & wave. \\
дыр. & A wave is competing with \\
Дулкын белән дулкын & another wave, \\
ярышкан. & Noisily consulting each \\
Киңәш итеп шау белән, \\
Бер өзлексез дау белән \\
Ярышып ярга барышкан. \\
*ж*
\end{tabular}




\begin{tabular}{|c|c|}
\hline $\begin{array}{l}\text { Сөя } \\
\text { Елаг } \\
\text { Көл } \\
\text { Жы } \\
\text { ж** } \\
\text { Шы. } \\
\text { тыр } \\
\text { Бере } \\
\text { урла } \\
\text { Дул } \\
\text { куад } \\
\text { Яры } \\
\text { Бир } \\
\text { Үлә, } \\
\text { тын } \\
\text { (tran } \\
\text { Isan }\end{array}$ & $\begin{array}{l}\text { While moving towards the } \\
\text { shore. } \\
* * * \\
\text { A wave is conversing in } \\
\text { confidential tones with an- } \\
\text { other wave, } \\
\text { Secretly feeling jealous, } \\
\text { One wave loves another, } \\
\text { A pearl girdled with foam } \\
\text { Catches your eye like a } \\
\text { snake, } \\
\text { Approaching the shore. } \\
* * * \\
\text { A wave loves and laughs. } \\
\text { The one that cries also } \\
\text { laughs, } \\
\text { The laughing one is the } \\
\text { one that dies, } \\
\text { They die crying and laugh- } \\
\text { ing. } \\
\text { *** } \\
\text { Making rumble and noise, } \\
\text { Stealing each other's se- } \\
\text { crets } \\
\text { One wave drives the other, } \\
\text { Giving honey to its be- } \\
\text { loved, } \\
\text { Dying here, } \\
\text { Dying, the wave becomes } \\
\text { quiet. }\end{array}$ \\
\hline
\end{tabular}

"In this last poem, love is shown in the form of a boundless and restless ocean, the movements of loving hearts correlate with the natural elements, for which the poet resorts to the homonyms "yar" ("shore" and "the chosen woman"). This poem demonstrates that Magzhan mastered symbolist techniques, like Derdemend and Blok had done, "which allowed him to expand the semantic field of words," was N. Isanbet's conclusion [Isanbet, pp. 9-11].

$\mathrm{N}$. Isanbet maintained close creative contacts with S. Kudash. Their assessments of $M$. Zhumabaev's poetry was almost the same: "This is a unique, original, and very talented poet. He has a unique style, amazing melodiousness, which is deeply rooted in the depths of folk poetry" (Quoted from: [Karimov, 2015]).

S. Kudash's appeal also remained unanswered.

The poems were returned to M. Zhumabaev thanks to N. Arslanov. In 1989, he published a translation of his poems with an introduction in the journal "Kazan utlary" ("The Lights of Kazan") [Arslan]. In 1994, M. Aglyam presented his trans-

\footnotetext{
${ }^{7}$ Мәрварит - red pearl, small coral - precious stones.
}

lations of the Kazakh poet's lyrical verses to the readers [Zhumabaev, pp. 134-138.]. In 2012, F. Tarkhanova contributed to the popularization of the Kazakh poet's works [Tarkhanova, pp. 93-94]. In 2013, the collection of poems "Zhan suze" ("The Voice of the Soul") by M. Zhumabaev was published to commemorate his $120^{\text {th }}$ birthday (compiled and translated by Radif Gatash). The collection is absolutely unique as it contains the translations made in different years by Tatar poets such as Radif Gatash, Nuri Arslanov, Mudaris Aglyamov, and Flera Tarkhanova.

N. Isanbet's article "Ber epigraph turynda" is an important source for studying the nature of the cultural and literary contacts between the Tatars and the Kazakhs in the twentieth century. N. Isanbet's translation of $\mathrm{M}$. Zhumabaev's lyrical works into the Tatar language serves to popularize his heritage among Tatar readers and testifies to the blazing talent of the Tatar and Kazakh writer.

In 1969, the Tatar and Bashkir writer Saifi Kudash appealed to the first secretary of the Central Committee of the Communist Party of Kazakhstan, Dinmukhammed Kunayev, to the first secretary of the Bashkir regional committee of the CPSU, Midkhat Shakirov, and to the Board of the Writers' Union of Kazakhstan (the first secretary Adi Sharipov) about the fate of the creative heritage of Magzhan Zhumabaev. He said, "I hope, I'm even sure that Kazakh writers and the party organization of Kazakhstan will find an opportunity to take a correct view of the complex early stages of their literature and return the work of one of its talented sons to its fold. Even regardless of his poetic heritage, what Magzhan Zhumabaev did is enough to remember and respect his name" (Quoted from [Karimov, 2015]). Thus, M. Zhumabaev's poems "Ut" ("Fire"), "Peygamber" ("Prophet") allow readers to have the idea of various Tatar poets' translation skills [Zhomabaev, 2013, pp. 20, 26, $33]$. The collection includes the translation of satirical poems by the Kazakh poet devoted to Tatars [Komabaev, 2013, pp. 78-79].

In 2019, R. Tufitullova published the novel "Yazmysh jile", which eternalizes the image of M. Zhumabayev. The work describes the period of his life in Petropavlovsk. In 1922-1923, he was the head of teacher training courses at the Kyzilyar Pedagogical School. At that time, he met a Tatar girl Gulsum Kamalova, who was a teacher there. She was brought to this land by the winds of the revolution. She and her husband Abdulla Akchurin were hiding from Communists among the Ka- 
zakhs. Gulsum made no secret of the fact that she was married.

In the novel, the reflections of Gulsum Kamalova are conveyed in the following way: "The poems by the Kazakh poet made a strong impression on me. Magzhan... It turned out that the Kazakh people have such a talented poet. He can be called Kazakh "Tukai"... His poems are consonant with Derdemend. Gulsum is reading, and her delight is growing" [Tufitullova, p. 80]. The work contains excerpts from the poems "To the Moon", "Ural", "The Voice of the Soul", "Gulsumkhanim". They allow readers to picture the poet's artistic world vividly. M. Zhumabaev dedicated the poem "Gulsum-khanim" to the youngest daughter of Zakir Kamali. It was translated into the Tatar language by N. Isanbet and F. Tarkhanova:

\begin{tabular}{|c|c|c|}
\hline $\begin{array}{l}\text { "Гөлсем } \\
\text { ханымга" }\end{array}$ & $\begin{array}{l}\text { "Гөлсем } \\
\text { ханымга" }\end{array}$ & $\begin{array}{l}\text { "Gulsum } \\
\text { khanim" }\end{array}$ \\
\hline $\begin{array}{l}\text { Бута күз }{ }^{8}, \\
\text { сихерлә сүз, } \\
\text { Гөлсем ханым, } \\
\text { Бер жирдә } \\
\text { үткәрсәк тә } \\
\text { гомер таңын, } \\
\text { Кайвакыт } \\
\text { күзегезгә күзем } \\
\text { төшсә, } \\
\text { Уйныйдыр } \\
\text { иләсләнеп нигә } \\
\text { каным? } \\
\text { Бута күз, сихер- } \\
\text { ле сүз, ханым } \\
\text { Гөлсем, } \\
\text { Күктә кояш } \\
\text { көлмәсен, } \\
\text { Гөлсем көлсен. } \\
\text { Гөлсем кояш, } \\
\text { күктә акрын } \\
\text { йөзә белә, } \\
\text { Сөйдереп } \\
\text { көйдергәнен ка- } \\
\text { ян белсен? } \\
\text { Н. Исәнбәт } \\
\text { тәржемәсе } \\
\text { гИсәнбәт]. }\end{array}$ & $\begin{array}{l}\text { Кара күз, } \\
\text { сихерлә сүз, } \\
\text { Гөлсем ханым, } \\
\text { Һәр жирдә } \\
\text { үткәрсәк тә } \\
\text { гомер таңын, } \\
\text { Кайвакыт } \\
\text { күзегезгә күзем } \\
\text { төшсә, } \\
\text { Уйныйдыр } \\
\text { иләсләнеп нигә } \\
\text { каным? } \\
\text { Кара күз, } \\
\text { сихерлә сүз, } \\
\text { Гөлсем ханым, } \\
\text { Күктә кояш } \\
\text { көлмәсен, } \\
\text { Гөлсем көлсен! } \\
\text { Гөлсем - кояш, } \\
\text { күккә акрын } \\
\text { йөзә белә, } \\
\text { Сөйдереп } \\
\text { көйдергәнен } \\
\text { каян белсен! } \\
\text { Ф.Тарханова } \\
\text { тәржемәсе } \\
\text { ГТарханова]. }\end{array}$ & $\begin{array}{l}\text { Baby camel eyes, } \\
\text { magic speech, } \\
\text { Gulsum khanim, } \\
\text { I look forward to } \\
\text { seeing you like to } \\
\text { the dawn, } \\
\text { When my eyes } \\
\text { suddenly meet } \\
\text { yours, Gulsum, } \\
\text { My heart throbs, } \\
\text { my mind is in } \\
\text { turmoil. } \\
\text { Baby camel eyes, } \\
\text { magic speech... } \\
\text { Flying like a } \\
\text { flame, you can } \\
\text { set fire } \\
\text { By making one } \\
\text { fall in love with } \\
\text { you, } \\
\text { Flashing like the } \\
\text { sun } \\
\text { With your smile, } \\
\text { radiant and } \\
\text { sweet, Gulsum! }\end{array}$ \\
\hline
\end{tabular}

In the novel, we see the image of the poet in a romantic spirit: "Magzhan ... His mind manifested itself in his outward appearance. However, his eyes exuded an indescribable melancholy and sadness.

\footnotetext{
${ }^{8}$ Бута күз - the eye of a camel colt in the Kazakh language is an epithet of beauty. Note by N. Isanbet.
}

Gulsum had never encountered such a deep, mysterious gaze, full of sadness before" [Tufitullova, p. 82].

Soon, the poet realized that his love was going to remain unrequited, and his beloved remained faithful to her husband. Magzhan's father was against this relationship; he matched him with D. Kuanashov's daughter. The bride-money was paid, but the poet did not appear at his own wedding, disappeared somewhere for three days, but it became known that he met his first love Zuleikha Zhaltyrova. They got married and left for Orenburg. The poet's devoted wife fought for him all her life, she kept his manuscripts, collected them bit by bit. She believed that after a decade, his work would return to his readers. In 1988, the poet's work was rehabilitated and the poems were published in the magazine "Friendship of Peoples".

In 2020, the novel "Yazmysh jile" ("The Wind of Fate") was published in Turkey under the name "Gulsum". The novel got a warm welcome among Turkish readers.

In the life of any nation, there are monumental personalities who reflect the fate of the whole nation. In 1920, M. Zhumabaev was already considered Abai Kunanbaev's successor. Tatars fell in love with his work the moment his first collection was published. And in the era when his legacy was banned, they stood up for the reputation of the poet of genius, put a lot of effort into returning his poems to the reader. At the beginning of the century, G. Ibragimov gave a helping hand to the Kazakh poet. In 1960, Kh. Makhmutov, N. Isanbet, $\mathrm{S}$. Kudash defended the brilliant Kazakh poet M. Zhumabaev and proved the need to return his legacy to readers. In 1990-2013, the Tatar poets N. Arslan, M. Aglyam, F. Tarkhanova, and R. Gatash published translations of the Kazakh Pushkin's poems and actively promoted his heritage. The image of M. Zhumabaev was immortalized by R. Tufitullova in the novel "Yazmysh zhile" ("The Wind of Fate"). The focus was on the story of the poet's love for the female enlightener Gulsum Kamalova. Thus, the Tatars made a huge contribution to the promotion of M. Zhumabaev's creative work and to the return of his heritage to readers.

\section{References}

Ahunov, A. M. (2010). Gyiffat tutash (Burnasheva Zahida Husaen kyzy) [Giffat Tutash (Burnasheva Zahida Khusain kyzy)]. Tatar entsiklopediyase: 6 tomda. 2 t.: G - J. Bash muharrir M. H. Khasanov, javaply muharrir G. S. Sabirjanov. Pp. 213-214. Kazan, 
"TR FAnen Tatar entsiklopediya instituty" deulet uchrezhdeniese. (In Tatar)

Eleukenov, Sh. (2008). Magzhan. Umiri men shygarmagerligi [Magzhan. Life and Works]. Astana. (In Kazakh)

Fattahova, L., Khabutdinova, M, Mashakova, A, Zamalieva, L. (2017). Tatar-Kazakh cultural and literary Connections at the Beginning of the XXI century. Turkish Online Journal of Design Art and Communication. Vol.7, pp.859-865. (In English)

Gainullin, M. Kh. (1975). Tatarskaia literatura XIX veka [Tatar Literature of the $19^{\text {th }}$ Century]. 308 p. Kazan', Tat. kn. izd-vo. (In Russian)

Gilazov, T. Sh. (2019). Raznostoronnii uchenyi, metodist $i$ nastavnik [A Great Scholar, Methodologist and Teacher]. TATARICA. No. 12 (1), pp. 172-175. (In Russian)

Galiullina, D. M. (2010). Gobaidullin Gaziz [Gubaidullin Gaziz]. Tatar entsiklopediyase: 6 tomda. 2 t.: G - J. / Bash muharrir M.H. Khasanov, javaply muharrir G. S. Sabirjanov. 132 p. Kazan, "TR FAnen Tatar enciklopediya instituty" deulet uchrezhdeniese. (In Tatar)

Ganieva, R. K. (1988). Vostochnyi Renessans i poet Kul Gali [Eastern Renaissance and the Poet Kul Gali].174 p. Kazan', izd-vo Kazan, un-ta. (In Russian)

Ganieva, R. K. (2003). Najip Dumavinyn ijat sahifelere [Najib Dumavi's Creative Works]. 108 p. Kazan, Otechestvo. (In Tatar)

Ganieva, R. K. Tvorchestvo G. Ibragimova $v$ kontekste zapadno-vostochnykh literatur (k 125-letiiu G. Ibragimova) [G. Ibragimov's Work in the Context of Western-Eastern Literatures (on the $125^{\text {th }}$ anniversary of G. Ibragimov)]. URL: http://e-history.kz/media/upload/ 1466/2014/07/28/824ad55e801e702a64559028e7d00d3 c.pdf_(accessed: 15.09.2020). (In Russian)

Gilazov, T. A great scholar, methodologist and teacher. Tatarica. 2019. №12 (1). pp. 172-175. (In Tatar)

Gilazeva, Ch. M. (2012). Edebiyat fane hem Gabdrahman Sagdi [Literary Studies and Gabdrakhman Sagdi]. 208 p. Kazan, RIC. (In Tatar)

Ibragimov, G. (1924). "Kara mayaklar yaki Ak edzeiyatlar" ["Black Lighthouses or White Literature"]. 70 p. Moscow, "Nashriyat" kooperativy. (In Tatar)

Ibragimov, G. (2019). Tellere bashka bulsa da, kunellere ber [Although Their Tongues Are Different, Their Hearts Are One]. (Matbugatta kazak jashlere tarafynnan kuzgatylgan tel meselese munesebete belen) (Ang. 1916. No. 5, pp. 87-90). Eserler: 15 tomda. Akademsik basma. 7 t. : Edəbiyat ham sangat turynda makalalar, hezmetler (1915-1916). Pp. 114- 120. Kazan, Tatar.kit.neshr. (In Tatar)

Isanbet, N. Ber epigraf turynda (G. Ibragimovnyn tuuyna - $80 \mathrm{el}$ ) [About One Epigraph (The $80^{\text {th }}$ Anniversary of G. Ibragimov)]. N. Isanbet shahsi arhivy. Kulyazma 11 bit. Mashinkada basylgan. Tatar telende. (In Tatar)

Iskakov, B. (1970). Kazakhsko-tatarskie literaturnye sviazi (Etapy razvitiya): Avtoreferat dis. na soiskaniye uchenoy stepeni kandidata filologicheskikh nauk [Kazakh-Tatar Literary Ties: (Stages of Development): Ph.D. Thesis Abstract]. (642) AN Kaz. SSR. In-t literatury i iskusstva im. M. O. Auezova. Alma-Ata, [b. i.], 39 p. (In Russian)

Kardesh halyklar shigriyatennen (1994) [From the Poetry of the Fraternal Peoples]. Kazan utlary. No. 2, pp. 135. (In Tatar)

Karimov, T. A. (2008). Gabdulla Tukai $i$ kazakhskaia intelligentsiia Zapadnogo Kazakhstana [Gabdulla Tukai and the Kazakh Intelligentsia of Western Kazakhstan]. Problemy formirovaniia ievraziiskogo myshleniia: Sb. mat-ov 5-oi Mezhdunar. nauch.-prak. konf. Pod red. R. Abuziarova. 220 p. Ural'sk. URL: http://gabdullatukay.ru/rus/tukay-science/ scientists/taufik-karimov-gabdulla-tukaj-i-kazahskayaintelligentsiya-zapadnogo-kazahstana/(accessed: 18.09.2020). (In Russian)

Karimov, T. A. Istoriia kazakhskoi knigi i tatarskie knigopechatniki [History of the Kazakh Book and Tatar Book Printers]. Proza.ru. URL: https://proza.ru/2015/ 06/15/1663 (accessed: 20.09.2020). (In Russian)

Karimov, T. A. K "Slovu o Magzhane" ili o nekotorykh voprosakh tvorcheskoy reabilitatsii kazakhskogo poeta Magzhana Zhumabaeva [On "The Word about Magzhan" or about Some Issues of the Creative Rehabilitation of the Kazakh Poet Magzhan Zhumabaev]. Proza.ru. URL: https://proza.ru/2015/07/ 31/590_(accessed: 21.09.2020). (In Russian)

Karimullin, A. (1979). Kazan telende basmalar [Publications in Kazan]. Karimullin A. Kitap dun'yasyna seyahet. 208 p. Kazan, Tatar.kit.neshr. (In Tatar)

Khabutdinova, M. M. (2018). "Kazaktaj jort” Galima Jajlybaia ["The Kazakh House" by Galim Gailybai]. M. Khabutdinova. Keruen. No. 1(58), pp. 133-147. (In Tatar)

Khabutdinova, M. M., Mashakova, A. K. (2019). Obraz Kazakhstana v tvorchestve A. M. Giliazova [The Image of Kazakhstan in the Works of A. M. Gilyazov]. Prostor. No. 1, pp. 175-182. (In Russian)

Khabutdinova, M. M., Mashakova, A. K. (2018). Sovremennye tatarskie publitsisty Kazakhstana [Modern Tatar Publicists of Kazakhstan]. Khabarshy. Vestnik. No. 1 (169), pp. 49-55. (In Russian)

Khabutdinova, M. M., Mashakova, A. K. (2018). Modern Tatar Publicists of Kazakhstan. Habarshy. Vestnik Kazakhskii natsional'nyi universitet imeni Al'Farabi. No.1 (169), pp. 49-55. (In English)

Mashakova, A. K., Khabutdinova, M. M. (2016). K voprosu ob etnicheskoi samoidentifikatsii tatar Kazakhstana (na materiale liriki sovremennykh tatarskik poetov) [On Self-Identity of Kazakhstan Tatars (based on the lyrical poetry of modern Tatar poets)]. Tatarica. No. 1, pp. 59-71. (In Russian)

Mashakova, A, Khabutdinova, M. (2017). The Creative Writings of Abay Kunanbayev in the Tatar Literary Reception. Espacios. Vol. 38, Is. 50, pp.1-8. (In English) 
Mashakova, A., Khabutdinova, M. (2019). History of the Tatars in Literature of Tatarstan and Kazahstan. Kul'turologiya, iskusstvovedenie i filologiya: sovremennye vzgliady i nauchnye issledovaniya. Sb. st. po materialam XXIII mezhdunar. nauch.-prakt. konf. No. 5 (21), pp. 107-111. Moscow, izd. "Internauka". (In English)

Minnegulov, H.Yu. (2020). Muhtar Auezov i tatary [Muhtar Auezov and the Tatars]. Minnegulov H.Yu. Gomerler uza iken ul. Pp. 284-290. Kazan, "Ihlas". (In Russian)

Minnegulov, Kh.Y. (2015). Abai i Tukai [Abay and Tukay]. Abay - elediik fenomen: Materialy mezhdunarodnoy konferentsii (Astana, 30 oktiabria 2015 g.). Astana, Universitet Nazarbayeva, pp. 281295. (In Russian)

Mukanov, K. (2009). Akyn izi. Sled poeta [The Poet's Trace]. Petropavlovsk. 339 p. (In Russian)

Nasyrova, A. M, Kabutdinov, A. Ju, Khabutdinova M. M. (2017). The Role of Prayer Discourse for Karaganda Concentration Camp. Image Creation in the Works of the Tatar Writer Ayaz Gilyazov and the Kazakh Poet Halim Zhaylybay. Astra Salvensis. Vol. 5, Is. 10, pp. 201-207. (In English)

Nurgali, R. (2004). Alashorodintsy (Alash $i$ literatura) [Alashorda (Alash and Literature)]. 272 p. Almaty, Alash. (In Russian)

Tarhanova, F. (2009). Kazahnyn shigri pejgambere [The Kazakh Poetic Prophet]. Kazan utlary. No. 6, p. 93. (In Tatar)

Tufitullova, R. (2019). Yazmysh jile. Roman [The Wind of Destiny. A Novel]. Kazan utlary. No. 4, 5. (In Tatar)
Yskakov, B. (1975). Kazah-tatar edebi bailanasy [Kazakh-Tatar Literary Ties]. 175 p. Almaty, Kazak SSSRniң “Gylym” basmasy. (In Tatar)

Zhanguttin, B. O. (2017). Magzhan Zhumabayev: stranitsy biografii [Magzhan Zhumabaev: Pages of His Biography]. Mir Bol'shogo Altaya. No. 3 (2), pp. 228241. (In Russian)

Zhetpisbaieva, B. A. Obraznyye miry Magzhana Zhumabayeva [Figurative Worlds of Magzhan Zhumabayev]. 156 p. Almaty, Nur-press. (In Russian)

Zhetpisbaieva, B. A. (2008). Obraznyye miry Magzhana Zhumabayeva [Figurative Worlds of Magzhan Zhumabayev]. 156 p. Izd. 2-ye, dop. Almaty, Nur-press. (In Russian)

Zhomabaev, M. (1989). Kazan utlary. No. 12, pp. 143. (In Tatar)

Zhomabaev, M. (2013). Jan suze. Shigyr'ler [Word of the Soul. Poems]. R. Korban tarj. 96 p. Kazan, Tatar. kit. nəshr. (In Tatar)

Zhomabaev, M. (1989). Jil. Shigyr'ler [The Wind. Poems]. N. Arslan tarj. Kazan utlary. No. 12, pp. 144145. (In Tatar)

Zhomabaev, M. (2009) Pajgamber. Shigyr'ler [The Prophet. Poems]. Kazan utlary. No. 6, pp. 94. (In Tatar)

Zhomabaev, M. (1994). Ut. Shigyr'lar [Fire. Poems]. M. Aglam tarj. Kazan utlary. No. 2, pp.136-138. (In Tatar)

Zhumabaeva, R. Magzhan v Moskve [Magzhan in Moscow]. map.nklibrary.kz. URL: www.map.nklibrary. kz/upload/pdf/ jumabaev/ inmoscow.pdf (accessed: 15.09.2020). (In Russian)

\title{
ТАТАР МӘДӘНИЯТЕНДӘ МӘГЬЖАН ЖОМАБАЕВ ИЖАТЫ РЕЦЕПЦИЯСЕ
}

\author{
Айнур Касыймжан кызы Машакова, \\ M.О. Ауэзов исемендәге Әдәбият һәм сәнгать институты, \\ Казахстан, 050010, Алматы ш., Курмангазы ур., 29 нчы йорт, \\ a_mashakova@mail.ru.
}

Миләүшә Мөхәммәтжан кызы Хәбетдинова, Казан федераль университеты, Россия, 420008, Казан ш., Кремль ур., 18 нче йорт, mileuscha@mail.ru.

\footnotetext{
Мәкалә татар һәм казах мәдәни һәм әдәби бәйләнешләренә багышланган. Татар мәдәниятендә казах шагыйре Мәгъжан Жомабаев тормыш юлы һәм ижатын төшенү һәм аңлау процессы, аның баскычлары тикшерү предметы булып тора. Шагыйрь әсәрләренең татарчага тәржемәләре, Н. Исәнбәтнең “Бер эпиграф тарихы” фәнни мәкаләсе, Р. Туфитуллованың “Язмыш жиле” романы чыганаклар буларак кулланыла. Архив материалларына таянып, татар галимнәре һәм язучыларының Сталин чоры корбаны булган күренекле казах шагыйре мирасын укучыларга яңадан кайтаруга керткән өлеше бәяләнә.
} 
Төп төшенчәләр: Казах-татар әдәби һәм мәдәни бәйләнешләре, татар әдәбияты, текстология, М. Жомабаев, Г. Ибраһимов, Н. Исәнбәт, С. Кудаш, Абай Кунанбаев, В. Брюсов, Н. Арслан, М. Әгъләм, Р. Гаташ, Ф. Тарханова, Р. Туфитуллова.

XIX гасыр ахырында татар мәгьрифәтчеләре белән тугандаш төрки халыклар арасында урнаша башлаган рухи жепләр XX гасыр башында, бу кавемнәрнең мөстәкыйль милләт булып аерымлану процессына нисбәтле, аеруча активлашып китә. Казан, Уфа шәһәрләрендәге, Россиянең башка төбәкләрендәге данлыклы "Мөхәммәдия", "Галия", “Хөсәения", "Мотыйгыя" һәм башка мәдрәсәләрдә башкорт, үзбәк, төрекмән, казах, кыргыз, комык, әзербайжан, кара-калпак, уйгур укучылары белем эстәүдән тыш, күренекле татар зыялылары Г. Ибраһимов, Н. Думави, Ш. Бабич, h.Такташ һәм башкалар төрки халыклар яшәгән төбәкләргә чыгып, жирле халык арасында мәгърифәт нуры чәчәләр, мәктәп мәдрәсәләрдә укыталар, вакытлы матбугат органнарында хезмәт итәләр. Бу бәйләнеш алга таба төрки-кардәш халыкларның мәдәниятләре hәм әдәбиятлары формалашуга ундырышлы жирлек әзерли. Әлеге традиция 1920-1930 елларда, идеологик һәм сәяси төсмер алып, планлы һәм системалы рәвештә алып барыла башлый. Г. Сәгъди, Н. Думави, Г. Гобәйдуллин, 3. Бурнашева (Гыйффәт туташ) һәм башка галимнәр, язучылар һәм жәмәгать эшлеклеләре тугандаш халыкларның гомуми урта һәм югары белем биру системасы, гуманитар фәннәре, милли мәдәниятләре үсешендә хәлиткеч роль уйныйлар. Татар һәм төрки-тугандаш халыклар арасындагы рухи һәм мәдәни бәйләнешләр тарихы галимнәрдә, ижат әһелләрендә зур кызыксыну уята (Р.К. Ганиева [Ганиева, 2002], А.М. Ахунов [Ахунов, 2010, ], Д.М. Галиуллина [Галиуллина, 2010], Ч.М. Гыйлажева [Гыйлажева, 2012 ], Т.Ш. Гыйлажев [Гилазов, 2019] һ.б.лар ).

Казах-татар мәдәни һәм әдәби бәйләнешләре дә татар hәм казах галимнәре тарафыннан даими өйрәнелеп килә (Б. Исхаков [Исхаков], [Ыскаков], M.X. Гайнуллин [Гайнуллин], Р.К. Ганиева [Ганиева, 1988], [Ганиева, 2014], А. Кәримуллин [Каримуллин], Х.Й. Миңнегулов [Миннегулов, 2015], [Миңнегулов, 2020], Т.А. Кәримов [Каримов, 2008], [Каримов, История...], [Каримов, К “Слову о Магжане"...].

Соңгы унъеллыкта М.О. Ауэзов исемендәге Әдәбият һәм сәнгать институты (Казахстан Республикасы) һәм Казан федераль университеты (Россия Федерациясе) галимнәренең хезмәттәшлеге кысаларында дистәләгән фәнни мәкалә дөнья күрде. (А.М. Насыйрова, М.М. Хәбетдинова, А.Ю. Хәбетдинов [Nasyrova, Khabutdinov, Khabutdinova], Л.Т. Фәттахова, А.К. Машакова, M.М. Хәбетдинова, Л.Ф. Жамалиева [Fattahova, Khabutdinova, Mashakova, Zamalieva], A.K. Машакова, M.M. Хәбетдинова [Mashakova, Khabutdinova, 2017], [Mashakova, Khabutdinova, 2018], [Mashakova, Khabutdinova, 2019], M.M. Хәбетдинова, А.К. Машакова [Машакова, Хабутдинова], М.M. Хәбетдинова [Хабутдинова]).

Казах галимнәре талантлы шагыйрь Мәгъжан Жомабаевның фажигале тормышын һәм ижатын өйрәнүгә зур өлеш кертәләр (Р. Нургали [Нургали], Ш. Елеукенов [Елеукенов], Б.А. Жетписбаева [Жетписбаева, 2008], [Жетписбаева 2012], К. Муканов [Муканов], Б.О. Жангуттин [Жангуттин]). Кызганычка каршы, татар галимнәренең һәм язучыларының шагыйрь ижатын өйрәну тарихындагы казанышлары әле дә системалаштырылмаган.

Мәгъжан Бекен улы Жомабаев 1893 елда Петропавел өязенең Полудин волостенда Сасыккүлдә дөньяга килә. Әтисе волость идарәчесе булганга, Мәгъжан шул заман өчен шактый югары белем алуга ирешә. Әүвәл өйдә, аннары авылдагы мәдрәсәдә укыганнан соң, 1910 елнын көзендә Уфадагы танылган «Галия» мәдрәсәсенә укырга керә (1909-1910). Ул Галимжан Ибраһимов, Шәехзадә Бабич, Мәжит Гафури, Сәйфи Кудаш кебек бик күп татар һәм башкорт язучылары белән аралашып яши. 1913 елда Мәгъжан Г. Ибраһимов киңәше белән Омскидагы укытучылар семинариясенә укырга керә. 1918 елда шагыйрьне кулга алалар һәм ул 7 ай төрмәдә утырып чыга.

Шагыйрьнең беренче “Чулпан” исемле китабы 1913 елда Казан шәһәрендә Кәримовлар типографиясендә басылып чыга. Н. Арслан фикеренчә, “лирик шигырьләр китабы белән Мәгъжанның зур талант иясе булу даны киң тарала" [Арслан]. 1922-1923 елларда Казанда hәм Ташкентта аның шигьри китаплары дөнья күрә.

Мәгъжан Жомабаев шагыйрь генә түгел, күренекле педагог та була. 1918 елда ул Омск hәм Петропавловск шәһәрләрендәге педагогик 
курсларның директоры вазифасын үти. 1922 елда Оренбургта аның «Педагогика» дигән китабы басылып чыга.

1922 елда М. Жомабаевны Ташкентка Казах-кыргыз мәгьрифәт институтына укытырга чакыралар. 1923 елның декабрендә Мәскәүкә килә. Анатолий Луначарский чакыруы буенча, Көнчыгыш хезмәт ияләренең коммунистик университетында көнчыгыш телләрен укыта. Казах мәктәпләре өчен дәреслекләр яза. 1923 елда Н. Тюракулов һәм проф. Поливанов рекомендацияләре белән М. Жомабаев Мәскәүнең В.Я. Брюсов исемендәге Әдәбият-сәнгать институтына укырга керә [Жангуттин, б. 228]. Мәскәүдә ул В. Брюсов, С. Есенин, Вс. Рождественский, О. Мандельштам, М. Светлов белән аралаша (Тулырак кара: [Жетписбаева, 2008], [Жетписбаева 2012]). Рус телен камил белгәнгә, А. Пушкин, А. Блок, М. Цветаева, А. Ахматова жыентыклары аның өстәл китабына әйләнә. Ул Гете, Гейне, Байрон, Лермонтов, Фет, Кольцов, Вс. Иванов шигырьләрен, М. Горький, Мамин-Сибиряк проза әсәрләрен казах теленә тәржемә итә [Жетписбаева, 2008, с. 14-15]. В. Брюсов үлеме сәбәпле, институт ябылу аркасында, М. Жомабаев укуын тәмамлый алмый. 1927-1929 елларда шагыйрь, Петропавелга кайтып, Казах педагогия техникумында укыта.

М. Жомабаевның ижатын яратучылар аңа Абайның дәвамчысы итеп карыйлар, ә пролеткультчылар - “буржуаз, милләтче, реакцион шагыйрь”, “алашист" дип бәялиләр. 1924 елда Мәскәүдә Көнчыгыш хезмәт ияләре коммунистик университеты киңәшмәсендә язучының ижаты идеологик яктан тотнаксыз дип раслана. Шул ук елның декабрендә Оренбургта аның ижатына багышланган Әдәби суд оештырыла. М. Жомабаев совет властена каршы язучы, дигән нәтижә ясала. Шагыйрь “Алка" исемле казах язучыларының ижат коллегиясенең программасын эшләү аркасында, 1929 елда милләтчелектә гаепләнеп, кулга алына. Мәскәу Бутыркасындагы сорау алулардан соң, ул Карелия лагерьларының берсенә жибәрелә. 1935 елда М Горькийга юллаган хатыннан соң, Жомабаев, бөек әдип hәм анын хатыны Е. Пешкова ярдәме белән,

\footnotetext{
${ }^{1}$ Алаш хәрәкәте - XX гасырның беренче чирегендә казахлар яшәгән территориядә Россия империясенең колониаль изү сәясәтенә каршы оешкан миллиазатлык хәрәкәте. Шушы хәрәкәт нигезендә 1917 1920 елларда «Алаш» партиясе барлыкка килә.
}

сөргеннән вакытыннан алда азат ителә. 1936-37 елларда ул яңадан Петропавелга кайта, А.С. Пушкин исемендәге мәктәптә рус теле һәм әдәбиятын укыта. 1937 елда шагыйрь һәм прозаик Сәкен Сейфуллин чакыруы буенча Алматыга килә. Монда аны яңадан кулга алалар həм 1938 елның мартында атып үтерәләр" [Тарханова, б. 93-94]. 1960 елның 8 июлендә Төркестан хәрби округының Хәрби трибуналы язучыны реабилитацияли, ләкин халыкка аның ижаты 1989 елда гына кире кайта ([Жомабаев, 1989], [Мәгъжан Жомабаев]).

1960 елда М. Жомабаев исемен һәм рухи мирасын халыкка кайтаруга татар, башкорт, казах язучылары бик күп көч салалар. 1965 елда филология фәннәре докторы, Казахстан дәүләт университетының профессоры Хәлиулла Мәхмүтов, "Простор" журналының баш мөхәррире Иван Шухов, тәржемәче Александр Жовтис М. Жомабаев шигырьләренең тәржемәләрен журналда басу өчен әзерләсәләр дә, цензура каршы килү сәбәпле, алар басылмый кала.

1967 елда Х. Мәхмүтов тагын бер омтылыш ясый. Казах дәүләт университетындагы филология факультетының жиде, ә журналистика факультетыннан ике кафедраның берләштерелгән утырышында М. Жомабаев ижатының әһәмиятен ассызыклап, аны укучыларга кайтару хакында доклад ясый. Галимне хуплап, язучы Тәхави Әхтәмов, профессор Тимергали Нуртазин, тәнкыйтьче Николай Ровенский, профессор Бәйсәнбай Кенжәбаев, язучы-тәржемәче Александр Жовтислар чыгыш ясый. Утырыш нәтижәләре нигезендә галимнәр Язучылар берлегенә М. Жомабаевның шигырьләрен һәм аның Ленин, Горький, Гете, Гейне, Лермонтов, Байрон әсәрләренең казах теленә тәржемәләрен нәшер итүне нәшриятлар планына кертүне үтенәләр.

$\mathrm{X}$. Мәхмүтов чыгышының копияләре hәм утырыш карарлары Казахстан ССР Мәдәният министры Ильяс Омаровка, СССР Югары Советының Милләтләре Советына, РСФСР Язучылар берлеге Идарәсенә язучы Леонид Соболевка һәм “Әдәби газета"га (Литературная газета) жибәрелә. Әмма Казахстан Компартиясе Үзәк Комитетының Фән һәм уку йортлары бүлеге бу инициативага тискәре карый hәм тикшеру башлана, Казахстан ССР КГБсыннан архив-жинаять эшләре буенча белешмәләр алына. Һәм Үзәк Комитет бюросының махсус утырышында 1967 елда шагыйрьнең әле акланмаганлыгы ассызыклана, шуңа да карамастан 
филологик кафедралар утырышларында “төп докладчы һәм чыгыш ясаучылар, шәхес культы елларында репрессияләнгән шагыйрьне казах поэзиясенең классигы санап, аны төрлечә зурларга омтылдылар" диелә. ҮК Бюросының “Жомабаевның рухи мирасын бәяләүдә КазДҮы филологик кафедраларының ялгыш карары” дигән постановлениесендә "Казах дәүләт университеты филологик кафедраларының милли-буржуаз шагыйрь Мәгъжан Жомабайның рухи мирасын бәләүдә ялгыш карарларын гаепләргә" дигән хөкем карары кабул итә" [Кәримов, 2015].

Нәкый Исәнбәт, 1965 елның жәендә шифаханәдә булу уңае белән, бер ай Алматы шәһәрендә яши həм казах галимнәре белән тыгыз аралаша. Галим М. Жомабаевны реабилитацияләүгә кулыннан килгән кадәр көч куя. Н. Исәнбәт архивында "Бер эпиграф турында" дигән мәкалә саклана [Исәнбәт]. Хезмәт 1967 елда язылган дип фаразлана, чөнки анда Г. Ибраһимовның 80 еллыгына багышланган искәрмә бар. Н. Исәнбәт күренекле татар язучысының һәм галименең дәрәжәсе, даны белән фәнни язманы да, М. Жомабаев шигырьләренең үзе әзерләгән тәржемәләрен дә бастырга омтылган, ләкин алар цензура аркасында "Казан утлары"нда чыкмыйча калганнар.

Н. Исәнбәт мәкаләсендә, казах шагыйренең тормыш юлын тасвирлаганда, М. Жомабаевның Мәскәудә Көнчыгыш хезмәт ияләре коммунистик университетында казах әдәбияты тарихын, казах теле стилистикасын укытуын билгеләп үтә. Язучының тәржемә өлкәсендә казанышлары турында язганда, шундый нәтижәгә килә: “Кыскасы, үзенең гыйльми әзерлеге, колачы ягыннан Мәгъжан Жомабаев совет көнчыгышында иң укымышлы, алдынгы әдәбият белгече, зур стилист hәм эре масштабтагы мәдәният эшчеләреннән берсе булган» [Исәнбәт, б. 5].

Татар матбугатында һәм "Чулпан" китабында басылган шигырьләре хакында уйланып, Н. Исәнбәт түбәндәге күзәтүләре белән уртаклаша: “Мәгьжан ул электән алган тәрбиясе буенча, казакъ әйтмешли, “муенына корык, авызына солык /авызлык/ кидерткән” шагыйрь түгел. Ул бары тик үз вөжданы алдында жавап бирүче, шуннан башка бер мәзһәбне дә танымаучы, ни уйласа шуны, үзе ничек ышанса шулай әйтүче, шулай язучы шагыйрь. Билгеле, шагыйрьлектә андый юл аңарчы ук электән килгән Байрон, Шиллер,
Пушкин, Лермонтов, Тукайлар кебек олы буыннар йоласы. Бу тип шагыйрьләргә заманында үзе яшәгән жәмгыять белән сыешып яшәү, гомумән дә, жиңел булмаганы билгеле" [Исәнбәт, б. 6], - дип яза.

Цензураны ялгыштыру өчен, мәкалә авторы шагыйрьнең остазлары турында сүз күтәрә. Автор карашынча, М. Жомабаевның шигъри таланты ачылуда Абай поэзиясе зур роль уйный: "Мәгъжан казах поэзиясенең нигез салучысы бөек Абай йогынтысында яза башлый. Аны остазы дип таный. Мәсәлән, аның "Атаклы акын, сүзе алтын Хәким Абайга" дигән мактау шигыре 1911 нче елда Өфедә укыган чагында ук язылган. Ул күп кенә шигырьләрен, Абай кебек үк, казах халык өләңе үлчәвендә, 11 ижекле итеп яза". Татар галиме М. Жомабаевның, сукырларча кабатлаудан качып, казах поэзиясендә үз сүзен әйтә алуын билгеләп китүне мөһим дип саный: “Ләкин Мәгъжан Абайга коры иярчән булып кына калмыйча, казах шигырен шул традицияләр нигезендә яңадан алга үстереп алып китә. Ул шигырьнең мәгънәсенә, кәефенә ятышлы рәвештә үлчәү юлларын, ритм һәм метрикасын яңача эшләтә. Шигырь теленә уйнак аваз яңгырашлыгы, яңача аһәңлелек кертә. Аңарда шигырь юллары 11 ижекле генә түгел, 4 ле, 5 ле, 6 лы, 7 ле һәм башка төрләнешләрдә үсеп чыга. Ул хис һәм мәгънәне аерым строфалар белән генә чикләп, таркатып бетерми, бәлки тоташ бер бөтен мәгънәле, бер бөтен кәеф, бер контекстлы шигырь язуга ирешә" [Исәнбәт, б. 6].

Н. Исәнбәт үз мәкаләсендә М. Жомабаевның 1911 елда Абайга багышлап язган шигыреннән өзек китерә:

Йөргән жанның - артында эзе калыр, Итекче үлсә, чүкеч белән безе калыр, Бер бай үлсә, дүрт төрледән ${ }^{2}$ малы калыр, Чичән үлсә, артында сүзе калыр.

Шомлы дөнья куштанланып күптән үтәр, Сау калганның күбесе иртән бетәр,

Туктамас бу дөньяның тәгәрмәче, Чичәннең ${ }^{3}$ әйткән сүзе күпкә житәр. (Казахчадан Н. Исәнбәт тәржемәсе)

2 Дүрт төрле мал /төрт түлік/ - ат, дөя, сыер, куйсарык. (Н. Исәнбәт искәрмәсе).

${ }^{3}$ Чичән - тел остасы, трибун, оратор. (Н. Исәнбәт искәрмәсе). 
Н. Исәнбәт үз мәкаләсендә казах шагыйренең әдәби дөньясы формалашуда, бер яктан, рус поэзиясе белән, икенче яктан, Европа мәдәнияте казанышлары белән танышуның да шифалы йогынтысын ассызыклый: "В.Я. Брюсов Мәгъжанны “кыргыз /казак/ Пушкины” дип атый. Чыннан да, бу шагыйрьдә шигырь булмаган бер генә юл сүз дә табалмыйсың. Билгеле, ул казах халык авыз ижаты һәм Абайлар традициясен, рус һәм Европа классикларын өйрәнгән һәм соңгы як русның Блок, Брюсовлар, символистлары белән дә кызыксынган» [Исәнбәт].

Мәкалә авторы М. Жомабаевның татар язучылары белән әдәби бәйләнешләре турында канәгатьләнү хисе белән яза: «Ләкин безнең өчен бигрәк тә әһәмиятлесе, аның татар поэзиясе белән турыдан-туры таныш булып кына калмыйча, аның алдынгы уңышларын да үзләштерүендә; шагыйрьләрдән бигрәк ул Тукай һәм Дәрдемәнд белән мавыккан.

Мәсәлән, аның бала йоклату турында "Бесік жыры" дигән озын гына бер шигыре турыдантуры Дәрдемәнднең "Бәллү"се тәэсире астында hәм үлчәвендә язылган. Мәгъжан халыкча, житез, тапкыр, очанак һәм жор телдә язуы белән Шәехзадә Бабичка да охшап куя. Хәер, алар икесе дә “Галия"дә укыганнар, тик Бабич сонрак кергәнгә, шәхси танышлыклары булганмы, юкмы, анысы миңа билгеле түгел» [Исәнбәт, б. 7].

Н. Исәнбәт М. Жомабаев белән Г. Ибраһимовның мөнәсәбәтләренә жентекле туктала. «Г. Ибраһимов белән Мәгъжан икесе дә “Галия"дә бер замандарак укыганга, алар шәхси дә таныш булган булырлар. Г. Ибраһимов 1924 тә язган "Кара маяклар" китабында Мәгъжанның исемен Абай Кунанбаев артыннан торган талантлы шагыйрьләрдән итеп телгә ала ${ }^{4} »$ [Кара маяклар яки Ак әдәбиятлар, б. 48], дип нәтижә ясый автор.

Н. Исәнбәт татар һәм казах телләрендәге кулъязма әдәби журналлар тирәсендә туган конфликтлы ситуацияне чишүдә $Г$. Ибраһимовның уңай ролен күрсәтә: «Бер заман Өфедә "Галия" мәдрәсәсендә әдәбият түгәрәге алып барган Шәехзадә Бабич татарча "Парлак" журналы чыгара. Казах шәкертләре дә калышмый, алар казахча “Садак” журналы чыгаралар. Бер-ике татар шәкертенең моңа эче поша: "Галия" татар мәдрәсәсе, монда нигә казахча чыгарыла?” дип, тавыш күтәрәләр.

\footnotetext{
${ }^{4}$ Сүз “Кара маяклар яки Ак әдәбиятлар" китабы турында бара [Кара маяклар яки Ак әдәбиятлар].
}

Милли мәсьәлә куба. Шунда тел-әдәбият укытучысы Галимжан Ибраһимов шәкертләрне зур залга жыя. Казах әдәби хәрәкәтенең хокукын яклап, ул житди доклад ясый. Бу докладында ул акын Кунанбаевлары, Сейфуллин, Дулатовлары кебек язучылары, үз телендә уку китаплары, газета-журналлары булган казах әдәбиятының инде тормыш факты булуын, аны күрмәмешкә салышу яки төрки халыкларны бер генә тел астына тупларга хыяллану ахмаклык икәнен исбат итә. Шәкертләр Г. Ибраһимов фикеренә кушылып, казах кардәшләрен тәбрик итәләр. (1913)».

Н. Исәнбәт Г. Ибраһимовның “Аң” журналының 1916 елгы 5 санында басылган "Телләре башка булса да, күнелләре бер" мәкаләсенә уңай бәя бирә [Ибраһимов, 2019, б. 114-120]: “Аның бу мәкаләсе аерым игьтибарга лаек. Г. Ибраһимов анда ул чордагы төрки телләрдәге әдәбиятның биш тармаклы бер агач булып үсүен әйтә. Алар: госманлы, әзербәйжан, татар, үзбәк, казак әдәбиятлары. Аларның берберсенә йогынтысы хакында сүз булырга мөмкин, ләкин алар һәрберсе берәр мөстәкыйль әдәбият, ди. Бу мәкаләдә безнең өчен хәзер бигрәк тә әһәмиятлесе шул әйбер: Г. Ибраһимов, казах тел-әдәбиятын яклап кына калмый, бәлки ул әдәбиятның үзенчә гүзәллегенә игътибар итә һәм аңа югары бәя биреп, безне аларның шундый уңышлы якларыннан өйрәнергә чакыра. Бу, әлбәттә, заманына күрә революцион дип әйтерлек һәм яңа сүз».

Тюркологлар хезмәтләренә таянып, Г. Ибраһимов үзенең мәкаләсендә, Н. Исәнбәт фикеренчә, казах әдәбиятының мөстәкыйльлеген яклап чыга: «Сүзләрен дәлилләү өчен, ул тюркологлар фикеренә таяна. Үз сүзләре белән әйткәндә, ул бу хакта менә нәрсә ди:

Тюркологлар hәммәсе казахларны иске төреклекнең иң нык сакланган жире, диләр. Бу көнгә казах халкы үзенең көнкүреше, хәят ихтыяжлары белән башка төрки кабиләләрдән бик нык аерылалар. Бу халыкның рухында бик куәтле самобытность бар. Боларның халык әдәбияты башка һичбер төрле кабиләнекенә охшамас дәрәжәдә бай һәм зурдыр. Безгә казахларны "татар теле вә татар әдәбияты" астына кертү хыялыннан бигрәк, әдәби хәзинәбезне баету өчен, казах халкы әдәбиятын

\footnotetext{
${ }^{5}$ Хәят - тормыш. (Н. Исәнбәт искәрмәсе)
} 
киң рәвештә өйрәнү тиешледер" [Ибраһимов, 2019, б. 117-118].

Н. Исәнбәт алга таба әдәбият галиме һәм жәмәгать эшлеклесе Ибраһимовның, авыр шартларга, вакыт кысынкылыгына карамастан, hәр гамәлендә татар милләтен яклавы, аның мәдәниятен үстерүгә гажәеп көч куюы турында яза: “Ләкин болай дип әйтүеннән Галимжан Ибраһимов төрки әдәбиятлардан бары тик казахныкына гына әһәмият биреп, башкаларны читләтә икән дип аңлашылмасын. Шунлыктан Г. Ибраһимовның эшчәнлеге турында сөйләгәндә, бу урында шуны да искә төшереп үтик. Татарстанда ачлык, жимереклек һәм шул ук вакыт сыйнфый көрәшләр эчендә автономияле яңа милли совет республикасы корылып яткан ут кебек кызу 22 нче елларда Г. Ибраһимовның гыйльми үзәк башында торган хәлдә, әдип буларак, зур-зур хикәя-романнарын төгәлләве билгеле. Үз әдәби эшчәнлеге өстенә шул ук вакыт ул тагын татар тел-әдәбият, тәнкыйть, гыйлем-мәгариф өлкәсендә, ягъни татар ижтимагый хәрәкәтенең үзәгендә торып, аның hәр тармагында үзенең сүзен-фикерен житкереп торырга да өлгерә»[Исәнбәт, б. 2].

Н. Исәнбәт, Г. Ибраһимовның "Казакъ кызы” романының эпиграфына ачыклык кертеп, текстологик искәрмә бирә: “Эпиграф астына тугыз нокта куелган. Бу М. Жомабаев /яки М. Жомабай / дигән хәрефләр санынча куелган булырга охшый” [Исәнбәт, б. 8].

Көң дала, көресің zой, ана жаткан,

Жібектей жасыл төптер бетін жапдан,

Аскар тау, балдан тәтте сулары бар,

Әнә сол анам өді мени талкан.

Киң дала, күрәсең ич, әнә яткан,

Ефәктәй яшел чирәм битен япкан,

Күктәш тау ${ }^{6}$, балдан татлы сулары бар,

Әнә шул анам иде, мине тапкан.

[М. Жомабаев “Айга”].

Н. Исәнбәт эпиграфның эчтәлеген болай билгели: “Тирән мәгънәле бу дүртьюллык эпиграф "Казакъ кызы" романына ачкыч урынында. Бу лейтмотив - романның темасының характерына авторның ишарәсе. Аны ачу Г. Ибраһимовның казах халкы белән булган әдәби, мәдәни мөнәсәбәтләрен ачарга

\footnotetext{
${ }^{6}$ Күктәш тау - күккә иш биек тау. Казахча “Аскар тау” сүзе, профессор Хәйрулла Мәхмүдов аңлатуынча, татарча шушы сүз белән бирелә. (Н. Исәнбәт искәрмәсе).
}

hәм, киресенчә дә, бу мөнәсәбәтләрне ачу безгә романны яхшырак аңларга ярдәм итәчәк” [Исәнбәт].

Н. Исәнбәт Г. Ибраһимовның казах халкына hәм аның мәдәниятенә сакчыл мөнәсәбәте турында яза: "Г. Ибраһимовның казах халык тел-әдәбият байлыгының үзенчәлеге хакындагы фикерләре, ул бәхәсләр килеп чыкканчы, электән үк аның башында туган булырга кирәк. Күп казаларга очраган "Казакъ кызы" романының 1 нче варианты 1909 нчы елларда ук язылган булуы шуны күрсәтә. Бу романның hәрбер жөмләсе казах халкына карата зур мәхәббәт белән сугарылган". Н. Исәнбәт язучының бу үзенчәлекле һәм бай мәдәнияткә мөрәжәгате очраклы гына булмаган дип саный, Г. Ибраһимов романтик буларак, бу төрки халыкның XX гасыр башында, буржуаз мөнәсәбәтләрнең корбаны булмыйча, Үз үзенчәлекләрен саклавына нык ышанган: "Революционер Галимжанның, әле капитализм формациясен дә кичәргә өлгермәгән һәм күчмәлеге өчен бәлки кимсетеп тә каралган казахларның чын хәленә кереп, роман язуы, әлбәттә, корыга гына түгел. Аның бер сәбәбе, ихтимал ки, буржуаз-мещанлык белән бозылып өлгермәгән казах халкының киң сәхрәви иркен табигатьләре, hәм табигыйлекләре нык сакланган булулары өчендәдер".

"Ирек-иркенлек турында романтик хыяллар белән ашкынган яшь Г. Ибраһимовның да атка атланып чабышта узыша торган казах кызы Карлыгачсылуларның идеаль гүзәллекләрен күрсәтүе үзе генә дә ул чагындагы татар дөньясы өчен ни тора! 16 нчы елда Ф. Бурнашның "Казах кызы” поэмасын язуы да бу романтик ашкынуларның гүзәл бер күренеше", - дип нәтижә ясый Н. Исәнбәт [Исәнбәт].

Мәкаләдә Н. Исәнбәт романны, бер яктан, язучының ижат лабораториясе, сәнгатьчә фикерләү үзенчәлеге, икенче яктан, аның теоретик эшчәнлеге, алар арасындагы бәйләнешләр контекстында тикшерә. Казах милләтенең бай халык авыз ижатын татар укучысына ирештерүдә, тугандаш халыкның тормышы сәнгатьчә зур осталык белән гәүдәләнүдә һәм бай казах теленең татар әдәби теленә уңай йогынтысында әсәрнең кыйммәте билгеләнә. "Г. Ибраһимов, әдип буларак, ул 10 нчы елларда романтик алымнарга бай булса да, шул ук вакыт, теоретик буларак, ул үзе ижтимагый реаль сәбәпләргә бик нык таянучан, галим буларак, каты фәнни метод һәм логик төшенчәләр белән эш итүче реалист кеше. 
Аның бу ике яклы табигате әдәби ижатында hәм шушы ук “Казакъ кызы”нда да бик үзенчәлекле һәм кызыклы чагыла. Ләкин эш анда гына түгел, эш тагы аның, югарыда үзе дә әйткәнчә, казах халкында бездә булмаган, яки булса да инде югалган төрләрдә зур һәм бай хәзинә сакланган булуын күрүендә. Бу хәзинә халык әдәбияты. Шунысы мөһим: Г. Ибраһимовның "Казакъ кызы" романы, кирәк, халыклар дуслыгына өлеш кертү ягыннан булсын, тирән тугандаш бер халыкнын эчке тормышын белеп, аңа тирән мәхәббәт һәм сәнгатьчә осталык белән язылу ягыннан булсын, әдәбиятыбызда зур урын биләп кенә калмый, ул әле бу әсәрендә казах халкы тел байлыгы, аның авыз ижаты алымнарыннан файдаланып, шуны татар-әдәби телен үстерешүдә стилистик әйләнешкә кертеп тә жибәрә, шуның белән баягыча үзе күтәреп чыккан тезисын бу әсәре белән үзе үк уңышлы рәвештә гамәлгә куеп күрсәтә. Бу ягы белән дә аның бу романы аның башка әдәби әсәрләре арасында аерым үзенчәлекле бер урын тота" [Исәнбәт, б. 4].

Г. Ибраһимов М. Жомабаевның пейзаж лирикасын язуда осталыгын, бу жанрның эчке хасияте, сурәтләнгән табигать күренешенең, шагыйрьнең, лирик герой - казахның рухи дөньясын үзенчәлекле ачу вазифасына нигезләнеп, югары бәяли: “Мәгъжанның шигырьдә тагы бер үзенчәлеге - пейзажшигырь язудагы осталыгы. Бу төр шигырьне казах поэзиясендә шундый киң күләмдә башлап ул тудырган дисәк тә, ялгыш булмастыр. Табигать анын шигырендә шагыйрь кәефе булып ачыла, жанлана, һәм лирик жылылык белән сугарылып, ул пейзаж шагыйрь әйтергә теләгән яна мәгънәнең сурәтенә әверелә, аның хис теле аша яңа бер тәгъбир булып яңгырый, Мәгъжанның палитры андый буяулар гаммасына һәм фоннарга гаять дәрәжәдә бай. Хәтта ки Галимжан Ибраһимов китергән шул дүртьюллык кына эпиграфта да моны яхшы күреп була: казах тиңдәш Алатавы, чиксез даласы белән бергә пейзаж - шигырьдә бер үк вакытта казах күңеленең дә шундый бөеклеге həм киңлеге тәгъбир ителә, бу киң табигать казахны тапкан ана хөкемендә аның үз табигате белән аермасыз дәрәжәдә бергә үрелгән, берберсен тудырышкан һәм шул нәрсә казахны казах иткән булуы әйтелә.

Г. Ибраһимов бу строфага шуның өчен дә аеруча игътибар иткән булса кирәк» [Исәнбәт].
Н. Исәнбәт казах шагыйре символистик алымнарны, Блок һәм Дәрдемәнд кебек үк уңышлы файдалана дигән фикердә тора. Бу, татар язучысы карашынча, М. Жомабаевның «Дулкын» шигырендә аеруча ачык чагыла:

\section{«Дулкын»}

Дулкыннан дулкын туадыр, Дулкынны дулкын куадыр.

Дулкын белән дулкын ярышкан.

Киңәш итеп шау белән,

Бер өзлексез дау белән

Ярышып ярга барышкан.

$$
* * *
$$

Дулкын белән дулкын серләшеп,

Сер алып, яшерен көнләшеп

Дулкынны дулкын сөядер,

Мәрварит ${ }^{7}$ күбеккә уралып,

Еландай йөзгә чормалып

Узышып ярга киләдер.

Сөядер дулкын, көләдер,

Елаганы-көлгәне,

Көлгәне аның -үлгәне,

Жылый-көлә үләдер.

$$
* * *
$$

Шылтыр-шылтыр шылтырап,

Беренең серен бере урлап,

Дулкынны дулкын куадыр,

Ярына бал бирәдер,

Бирәдер дә үләдер,

Үләдер дулкын, тынадыр.

(Казахчадан Н. Исәнбәт тәржемәсе) [Исәнбәт].

«Бу соңгы шигырьдә мәхәббәтнең диңгез кебек чиксез һәм ашкынулы булуы, йөрәкнең үз сөйгән ярына атлыгулары да шул диңгезнең ярга ташланулары сурәтендә табигать стихиясе итеп бирелә, моның өчен адаш сүз “яр" аша ишарә ясала. Мәгъжанда кайбер шундый төр шигырьләрнең дә очраштыруы аның, Дәрдемәнд hәм Блоклар кебек, тирән һәм нечкә кинаяле мәгънәдәге символизм алымнары белән шигырь язуга да сәләтле булуын күрсәтә» [Исәнбәт, б. 911] дигән нәтижәгә килә Н. Исәнбәт.

Н. Исәнбәтнең «Бер эпиграф турында» мәкаләсе XX гасырда татар-казах мәдәни hәм әдәби контактлар характерын өйрәнү өчен мөһим чыганак булып тора. Язучы һәм галимнең М.Жомабаев лирикасын татар теленә тәржемәләре, бер яктан, аның мирасын татар укучылары арасында популярлаштыру булып торса, икенче яктан, татар һәм казах язучыларының көчле сәләтләрен ачык күрсәтәләр.

\footnotetext{
${ }^{7}$ Мәрварит - кыйммәтле гали, мәрван таш.
} 
1969 елда татар һәм башкорт язучысы С. Кудаш Казахстан Компартиясе Үзәк Комитетының беренче секретаре Динмөхәммәт Кунаевка, КПССның Башкортостан өлкә комитеты беренче секретаре Мидхәт Шакировка һәм Казахстан Язучылар бүлеге Идарәсенә (беренче секретарь Ади Шәрипов) Мәгъжан Жомабаев ижади мирасының язмышы турында мөрәжәгать итә: "Мин казах язучыларының, Казахстан партия оешмасы ярдәме белән, Үз әдәбиятларының катлаулы башлангыч этапларын дөрес бәяләп, талантлы улларыннан берсенең ижатын аның кочагына кайтару мөмкинлекләре табуларына ышанам. Аның тарафыннан тудырылган житәрлек рухи мирасны исәпкә алмаганда да, Мәгъжан Жомабаевны искә алу һәм аның исемен хөрмәт итү өчен булса да" [Кәримов, 2015].

Н. Исәнбәт С. Кудаш белән тыгыз элемтәдә тора. Язучыларның М. Жомабаев поэзиясенә бәяләмәләре дә бер-берсенә аваздаш: “Ул үзенчәлекле, үзенә бер һәм бик талантлы шагыйрь. Ул үзенә генә хас язу стиленә, чишмә башы халык шигьриятенең тирәнлегендәге гажәеп көйгә ия" [Кәримов, 2015]. Кызганыч ки, С. Кудашның да мөрәжәгате жавапсыз кала.

Татар укучысына М. Жомабаевның ижатын кайтаруны Нури Арсланов башлап жибәрә. 1989 елда язучы “Казан утлары" журналында кереш сүз белән үзенең тәржемәләрен бастыра [Арслан]. 1994 елда М. Әгъләм казах язучысының шигырьләренең тәржемәләрен укучыларга бүләк итә [Жомабаев, б. 134-138]. 2012 елда Ф. Тарханова да казах шагыйренең ижатын популярлаштыруга Y3 өлешен кертә [Тарханова, б. 93-94]. 2013 елда Мәгъжан Жомабаевның тууына 120 ел тулу уңае белән, татар телендә «Жан сүзе» жыентыгы басылып чыкты (Төзүчесе, төп тәржемәчесе - Рәдиф Гаташ). Төрле елларда бер үк шигырьләрнең татар язучылары Н. Арслан, М. Әгъләм, Ф. Тарханова, Р. Гаташның тәржемәләре туплануда бу жыентыкның үзенчәлеге, уникальлеге билгеләнә. Мәсәлән, М. Жомабаевның "Ут", “Пәйгамбәр" шигырьләре мисалында, укучылар язучыларның тәржемәче буларак осталыклары турында фикер туплый алалар. [Жомабаев, 2013, б. 20, 26, 33]. Жыентыкта М. Жомабаевның татарларга нисбәтле язылган сатирик шигырьләре дә урын тапкан [Жомабаев, 2013, б. 78-79].

2019 елда Р. Туфитуллованың М. Жомабаев образы мәңгәлештерелгән “Язмыш жиле" романын нәшер итте. Әсәрдә казах язучысы тормышының Петропавел чоры тасвирлана. 1920-1922 елларда ул Кызылъяр педагогия училищесында оештырылган педагогик курсларның директоры булып эшли. Шул ук вакытта монда Гөлсем Камалова дигән татар кызы да укыта. Аны бирегә инкыйлабның дәһшәтле дулкыннары китереп ташлаган була. Ул ире Абдулла Акчурин белән, коммунистлардан качып, казахлар арасына сыена. Гөлсем никахлы хатын булганын яшерми.

Романда Гөлсөм Камалова уй-фикерләре шулай итеп сурәтләнә: “Казах шагыйренең дә шигырьләре мине нык тәэсирләндерде. Мәгъжан... Казах халкының да менә нинди талантлы шагыйре бар икән. Казахның «Тукае» диярлек... Дәрдемәнднең шигъри авазлары да яңгырап китә. Гөлсем укый, укыган саен таң кала”. [Туфитуллова, б. 80]. Әсәрдә “Айга", "Урал”, “Жан авазы”, “Гөлсем ханымга" шигырьләреннән, поэмаларыннан өзекләр очрый. Алар укучыда шагыйрьнең әдәби дөньясы турында күзаллау формалаштыруга мөмкинлек бирәләр. М. Жомабаев, Закир Камалинең төпчек кызына багышлап, «Гөлсем ханымга" дигән шигырен яза. Аны татар теленә Н. Исәнбәт һәм Ф. Тархановалар тәржемә иткәннәр.

\begin{tabular}{|c|c|}
\hline${ }^{\prime \prime} \Gamma$ & ${ }^{\prime \prime} \Gamma$ \\
\hline $\begin{array}{l}\text { Y3}^{8}, \text { сихерлә сүз, } \\
\text { м ханым, } \\
\text { трдә үткәрсәк тә } \\
\text { таңын, } \\
\text { кыт күзегезгә күзем } \\
\text { идыр иләсләнеп } \\
\text { аным? }\end{array}$ & $\begin{array}{l}\text { Кара күз, сихерлә сүз, } \\
\text { Гөлсем ханым, } \\
\text { һәр жирдә үткәрсәк тә } \\
\text { гомер таңын, } \\
\text { Кайвакыт күзегезгә күзем } \\
\text { төшсә, } \\
\text { Уйныйдыр иләсләнеп } \\
\text { нигә каным? } \\
\text { Кара күз, сихерлә сүз, } \\
\text { Гөлсем ханым, } \\
\text { Күктә кояш көлмәсен, } \\
\text { Гөлсем көлсен! } \\
\text { Гөлсем - кояш, күккә } \\
\text { акрын йөзә белә, } \\
\text { Сөйдереп көйдергәнен } \\
\text { каян белсен! } \\
\text { (Ф.Тарханова тәржемәсе) }\end{array}$ \\
\hline
\end{tabular}

Без романда романтик рухлы шагыйрь образы белән очрашабыз: "Мәгъжан...

\footnotetext{
${ }^{8}$ Бута күз - тәвә баласы күзе. Казакта матурлык эпитеты булып йөри. Н. Исәнбәт искәрмәсе.
} 
Зыялылыгы кыяфәтенә чыккан. Әмма жаныннан, күзләреннән әйтеп бетергесез сагыш, моң саркый. Бу кадәр дә моңсу, тирән, сихри карашка Гөлсемнең моңарчы юлыкканы да юк шикелле" [Туфитуллова, б. 82].

Шагыйрь сөйгәненең иренә тугъры каласын, мәхәббәтенең жавапсыз булачагын тиз аңлый. Мәгъжанның әтисе бу мәхәббәткә каршы төшә, малаена Д. Куанашов кызын димли. Калым түләнә. Шагыйрь, үз туена килмичә, өч көн югалып йөри. Соңыннан гына аның Хәрбиннан кайткан беренче мәхәббәте Зөләйха Жалтырова белән күрешүе ачыклана. Алар өйләнешеп, Оренбург шәһәренә китәләр. Шагыйрьнең хатыны гомер буе ире өчен көрәшә, кулъязмаларын бөртекләп жыеп, яшереп саклый. Ул иренең ижаты дистә еллардан соң Үз укучысына кайтачагына ышана. 1988 елда шагыйрь ижаты реабилитацияләнә һәм шигырьләре "Халыклар дуслыгы" (Дружба народов) журналында дөнья күрә.

Р. Туфитуллованың “Язмыш жиле" әсәре 2020 елда Төркиядә "Гөлсем" исеме белән басылып чыга. Төрек укучылары романны жылы кабул итәләр.

һәрбер милләтнең һәм халык тормышында хәлиткеч роль уйнаган шәхесләр була, аларның ижатында үз милләтенең язмышы чагыла. 1920 елда ук М. Жомабаевта Абай Кунанбаев шәкертен, аның эзеннән баручыны күрәләр. Татарлар шагыйрьне, беренче шигырь жыентыгы басылып чыгу белән, яратып өлгерәләр; аның рухи мирасы тыелгач, атаклы шагыйрьнең намуслы исемен яклап чыгалар, шигырьләрен укучыга кайтаруга кулларыннан килгән кадәр көч куялар. Гасыр башында $Г$. Ибраһимов ярдәм кулы сузган. 1960 елларда Х. Мәхмүтов, Н. Исәнбәт, С. Кудашлар бөек казах шагыйре М. Жомабаевны яклап чыкканнар һәм аның мирасын укучыларга кайтару кирәклеген нигезләгәннәр. 1990 - 2013 елларда татар шагыйрьләре $\mathrm{H}$. Арслан, М. Әгъләм, Ф. Тарханова, Р. Гаташ “казах Пушкины” шигырьләренең тржемәләрен нәшер иттеләр, аның рухи мирасын актив рәвештә пропагандаладылар. М. Жомабаев ялкынлы образы Р. Туфитуллованың “Язмыш жиле" романында мәңгәләштерелде. Әсәрдә шагыйрьнең мәгърифәтче Гөлсем Камаловага мәхәббәт тарихы игътибар үзәгенә куела. Димәк, татарлар М. Жомабаев ижатын пропагандалауга һәм аның мирасын укучыларга кайтаруга зур өлеш кертәләр.

\section{Әдәбият}

Ахунов А.М. Гыйффәт туташ (Бурнашева Заһидә Хөсәен кызы) // Татар энциклопедиясе: 6 томда. 2 т.: Г - Й. / Баш мөхәррир М.Х. Хәсәнов, жаваплы мөхәррир Г.С. Сабиржанов. Казан: «ТР ФАнең Татар энциклопедия институты» дәүләт учреждениесе, 2010. Б. 213-214.

Гайнуллин M.X. Татарская литература XIX века. Казань: Тат. кн. изд-во, 1975. 308 с.

Галиуллина Д.М. Гобәйдуллин Газиз // Татар энциклопедиясе: 6 томда. 2 т.: Г - Й. / Баш мөхәррир М.Х. Хәсәнов, жаваплы мөхәррир Г.С. Сабиржанов. Казан: «ТР ФАнең Татар энциклопедия институты» дәүләт учреждениесе, 2010. Б.132.

Ганиева P.К. Восточный Ренессанс и поэт Кул Гали. Казань: изд-во Казан, ун-та, 1988. 174 с.

Ганиева Р.К. Нәжип Думавиның ижат сәхифәләре. Казан: Отечество, 2003. 108 б.

Ганиева P.К. Творчество Г. Ибрагимова в контексте западно-восточных литератур (к 125летию Г.Ибрагимова) // URL: http://e-history.kz/ media/upload/1466/2014/07/28/824ad55e801e702a6455 9028e7d00d3c.pdf (Мерәжәгать итү вакыты: 15.09.2020).

Гыйлажев Т.Ш. Киң колачлы галим, методист һәм остаз. // Tatarica. 2019. №12 (1). C. 172-175.

Гыйлажсева Ч.М. Әдәбият фәне һәм Габдрахман Сәгъди. Казан: РИЦ, 2012. 208 б.

Елеукенов Ш. Мағжан. Өмірі мен шығармагерлігі. Астана, 2008.

Жангуттин Б.О. Магжан Жумабаев: страницы биографии // Мир Большого Алтая. 2017. №3 (2). 228-241.

Жетписбаева Б.А. Образные миры Магжана Жумабаева. Алматы: Нурпресс, 156 с.

Жетписбаева Б.А. Образные миры Магжана Жумабаева. Изд. 2-е, доп. Алматы: Нур-пресс, 2008. $156 \mathrm{c}$.

Жумабаева Р. Магжан в Москве [Электронный pecypc] // map.nklibrary.kz, URL: www.map.nklibrary. kz/upload/pdf/ jumabaev/ inmoscow.pdf (Мөрәжәгать итү вакыты: 15.09.2020).

Жомабаев М. // Казан утлары. 1989. №12. Б. 143.

Жомабаев М. Жан сүзе. Шигырьләр / Р. Корбан тәрж. Казан: Татар. кит. нәшр., 2013. 96 б.

Жомабаев М. Жил. Шигырьләр / Н. Арслан тәрж. // Казан утлары. 1989. №12. Б. 144-145.

Жомабаев М. Пәйгамбәр. Шигырьләр // Казан утлары. 2009. №6. Б.94.

Жомабаев М. Ут. Шигырьләр / М. Әгъләм тәрж. // Казан утлары. 1994. №2. Б.136-138.

Ибраһимов Г. "Кара маяклар яки ак әдәбиятлар" М.: «Нәшрият» кооперативы, 1924. 70 б.

Ибраһимов Г. Телләре башка булса да, күңелләре бер. (Матбугатта казакъ яшьләре тарафыннан кузгатылган тел мәсьәләсе мөнәсәбәте белән) (Аң. 1916. № 5. Б. 87-90) // Әсәрләр: 15 томда. Академсик басма. 7 т. : әдәбият һәм сәнгать 
турында мәкаләләр, хезмәтләр (1915-1916). Казан: Татар.кит.нәшр., 2019. Б. 114- 120.

Исәнбәт H. Бер эпиграф турында (Г. Ибраһимовның тууына - 80 ел) // Н. Исәнбәт шәхси архивы. Кулъязма 11 бит. Машинкада басылган. Татар телендә.

Искаков Б. Казахско-татарские литературные связи [Текст]: (Этапы развития): Автореферат дис. на соискание ученой степени кандидата филологических наук. (642) / АН Каз. ССР. Ин-т литературы и искусства им. М. О. Ауэзова. Алма-Ата : [б. и.], 1970.39 c.

Кардәш халыклар шигъриятеннән // Казан утлары. 1994. №2. Б.135.

Каримов Т.А. Габдулла Тукай и казахская интеллигенция Западного Казахстана // Проблемы формирования евразийского мышления: Сб. мат-ов 5-ой Междунар. науч.-прак. конф. / Под ред. P.А.Абузярова. Уральск, 2008. 220 с. // URL: http:/gabdullatukay.ru/rus/tukay-science/scientists/ taufik-karimov-gabdulla-tukaj-i-kazahskayaintelligentsiya-zapadnogo-kazahstana/(Мөрәжәгать итү вакыты: 18.09.2020).

Каримов Т.А. История казахской книги и татарские книгопечатники // proza.ru URL: https://proza.ru/2015/06/15/1663 (Мөрәжәгать итү вакыты: 20.09.2020).

Каримов Т.A. К "Слову о Магжане" или о некоторых вопросах творческой реабилитации казахского поэта Магжана Жумабаева // proza.ru URL: https://proza.ru/2015/07/31/590 (Мөрәжәгать итү вакыты: 21.09.2020).

Кәримуллин Ә. Казан телендә басмалар // Кәримуллин Ә. Китап дөньясына сәяхәт. Казан: Татар.кит.нәшр., 1979. 208 б.

Машакова А.К., Хабутдинова М.М. К вопросу об этнической самоидентификации татар Казахстана (на материале лирики современных татарских поэтов). // Tatarica. 2016. №1. С. 59-71.

Миннегулов Х.Ю. Мухтар Ауэзов и татары // Миннегулов Х.Ю. Гомерләр уза икән ул. Казан: “Ихлас", 2020. Б. 284-290.

Миңнегулов Х.Й. Абай и Тукай // Абай - әледиік феномен: Материалы международной конференции (Астана, 30 октября 2015 г.). Астана: Университет Назарбаева, 2015. С. 281-295.
Мұқ̆анов К. Ақын ізі. След поэта. Петропавловск, 2009. 339 с.

Нургали Р. Алашординцы (Алаш и литература). Алматы: Алаш, 2004. 272 с.

Туфитуллова Р. Язмыш жиле. Роман // Казан утлары. 2019. №4, 5.

Тарханова Ф. Казахның шигъри пәйгамбәре // Казан утлары. 2009. №6. Б.93.

Хабутдинова М.M «Казакътай йорт« Галима Жайлыбая // М. Хабутдинова // Керуен. 2018. №1(58). C. 133-147.

Хабутдинова М.М., Машакова А.К. Образ Казахстана в творчестве А.М. Гилязова // Простор. 2019. №1. C.175-182.

Хабутдинова М.М., Машакова А.К. Современные татарские публицисты Казахстана // Хабаршы. Вестник. 2018. №1 (169). С.49-55.

Ыскаков Б. Казах-татар әдәби байланасы. Алматы: Казак СССРнің “Гылым” басмасы, 1975. 1756.

Fattahova L., Khabutdinova M, Mashakova A, Zamalieva L. Tatar-Kazakh cultural and literary Connections at the Beginning of the XXI century//Turkish Online Journal of Design Art and Communication. 2017. Vol.7, Is. Pp. 859-865.

Khabutdinova M.M., Mashakova A.K. Modern Tatar publicists of Kazakhstan // Хабаршы. Вестник Казахский национальный университет имени АльФараби. 2018. №1 (169). Рp. 49-55.

Mashakova A, Khabutdinova M., The creative writings of Abay Kunanbayev in the Tatar literary reception // Espacios. 2017. Vol. 38, Is.50. Pp. 1-8.

Mashakova A., Khabutdinova $M$. History of the Tatars in Literature of Tatarstan and Kazahstan // Культурология, искусствоведение и филология: современные взгляды и научные исследования. сб. ст. по материалам XXIII междунар. науч.-практ. конф. № 5 (21). М., Изд. «Интернаука», 2019. С.107111.

Nasyrova A.M, Khabutdinov A.J, Khabutdinova $M . M$, The role of prayer discourse for karaganda concentration camp image creation in the works of Tatar writer Ayaz Gilyazov and the Kazakh poet Halim Zhaylybay//Astra Salvensis. 2017. Vol.5, Is.10. Pp. 201207. 


\title{
РЕЦЕПЦИЯ ТВОРЧЕСТВА МАГЖАНА ЖУМАБАЕВА В ТАТАРСКОЙ КУЛЬТУРЕ
}

\author{
Айнур Касымжановна Машакова, \\ Институт литературы и искусства имени М.О.Ауэзова, \\ Казахстан, 050010 г. Алматы, ул.Курмангазы, д. 29, \\ a_mashakova@mail.ru.
}
Милеуша Мухаметзяновна Хабутдинова, Казанский федеральный университет, Россия, 420008, г. Казань, ул. Кремлевская, д. 18, mileuscha@mail.ru.

\begin{abstract}
Статья посвящается проблеме татарско-казахских литературных и культурных взаимосвязей. Предметом изучения становятся рецепция творчества казахского поэта Магжана Жумабаева в татарской культуре. В качестве источников используются татарские переводы произведений поэта, статья Н. Исанбета “История одного эпиграфа”, роман Р. Туфитулловой "Ветер судьбы”. Опираясь на архивные материалы, выявлен вклад татарских ученых и писателей в возвращение наследия известного казахского поэта, ставшего жертвой сталинских репрессий.
\end{abstract}

Ключевые слова: Казахско-татарские литературные и культурные взаимосвязи, татарская литература, текстология, М. Жумабаев, Г. Ибрагимов, Н. Исанбет, С. Кудаш, Абай Кунанбаев, В. Брюсов, Н. Арслан, М. Аглям, Р. Гаташ, Ф. Тарханова, Р. Туфитуллова. 